UCRL 8708
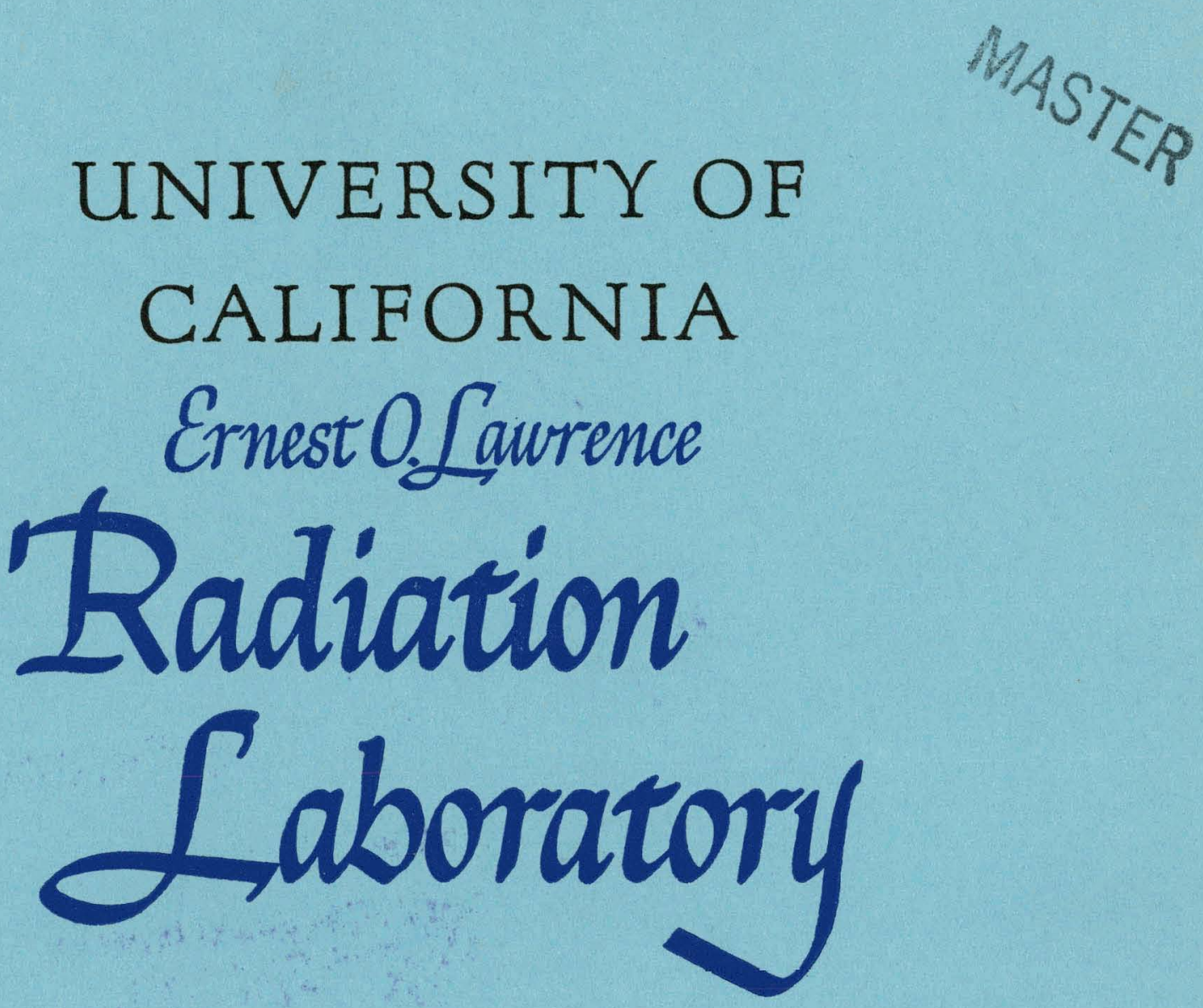

\title{
THE EFFECTS OF INDOLEACTIC ACID AND KINETIN ON THE GROWTH OF SOME MICROORGANISMS
}

BERKELEY, CALIFORNIA 


\section{DISCLAIMER}

This report was prepared as an account of work sponsored by an agency of the United States Government. Neither the United States Government nor any agency Thereof, nor any of their employees, makes any warranty, express or implied, or assumes any legal liability or responsibility for the accuracy, completeness, or usefulness of any information, apparatus, product, or process disclosed, or represents that its use would not infringe privately owned rights. Reference herein to any specific commercial product, process, or service by trade name, trademark, manufacturer, or otherwise does not necessarily constitute or imply its endorsement, recommendation, or favoring by the United States Government or any agency thereof. The views and opinions of authors expressed herein do not necessarily state or reflect those of the United States Government or any agency thereof. 


\section{DISCLAIMER}

Portions of this document may be illegible in electronic image products. Images are produced from the best available original document. 
UCR L- 8708

Biology and Medicine

\section{UNIVERSITY OF CALIFOR NIA \\ Lawrence Radiation Laboratory \\ Berkeley, California}

Contract No. W-7405-eng-48

THE EFFECTS OF INDOLEACETIC ACID AND KINETIN ON THE GROWTH OF SOME MICROOR GANISMS

David Kennell

(Thesis)

$\operatorname{March~31,1} 1959$

Printed for the U.S. Atomic Energy Commission 
Printed in USA. Price $\$ 2.00$. Available from the office of Technical Services U.S. Wepartment of Commerce Washington:25, :D. C. 


\section{Contents}

Abstract $\quad 4$

Introduction $\quad 6$

Known Effects of Indoleacetic Acid on Plants 9

Known Effects of IAA on Microorganisms

Conclusions from Known Effects of IAA 12

The Discovery of Kinetin 13

Known Effects of Kinetin $\quad 14$

Conclusions from Known Effects of Kinetin 15

Purpose of These Experiments 16

Procedures, Results and Conclusions

Amoeba proteus $\quad 18$

$\begin{array}{ll}\text { Methods and Materials } & 18\end{array}$

Effects of IAA and Kinetin.on Growth in Amoebae 18

Escherichia coli

Methods and Materials . . 22

Effects of Kinetin on Growth in Bacteria 22

The Relation of Kinetin to Adenine . . 24

Yeast

Methods and Materials . . . 26

Effects of IAA on Culture Growth in Yeast 29

Effects of Kinetin on Culture Growth in Yeast. 29

Individual-Cell Growth Studies . 35

Alteration of Cells by Kinetin 38

Cytological Considerations . . . 39

Interpretation of Results : · 42

Specificity of Kinetin . . . 44

Discussion

Indoleacetic Acid 45

Kinetin . . 47

Ribonucleic Acid and Protein Sýnthesis 48

Kinetion and Ribonucleic Acid 53 
Kinetin in Biolögical Material 54

Kinetin and Cell Division .. 55

Evidence for Internal Regulation of Cell Growth ...

Purpose of the Study $\quad 57$

Cell Growth in Starvation Medium . : $\quad 57$

Acknowledgments $\quad 65$

Bibliography $\quad 66$ 
THE EFFECTS OF INDOLEACETIC ACID AND KINETIN ON'THE GROWTH OF SOME MICR OOR GANISMS

\author{
David Kennell \\ Lawrence Radiation Laboratory \\ and Donner Laboratory of:Biophysics and Medical Physics \\ University of California, Berkeley, California \\ March 31, 1959
}

ABSTRACT

The growth rates of Amoeba proteus, Escherichia coli bacteria, and two species of yeast are changed by. the presence of kinetin and (or) the plant auxin, indoleacetic acid.

The growth rate of Amoeba proteus is increased by the presence of kinetin. Indoleacetic acid has no apparent effect on this cell.

Kinetin increases the growth rate of Escherichia coli in a salts-glucose medium. Adenine also accelerates growth. However, isotopic-competition experiments indicated that kinetin does not compete with adenine; it must be incorporated into different compounds.

IAA depresses the culture growth rate of the yeasts Saccharomyces cerevisiae and Schizosaccharomyces pombe. This decrease can be accounted for entirely as a change in the interphase growth rate of the individual cell.

Kinetin, by itself, has no apparent effect on yeast growth. In the presence of IAA, kinetin, over a wide concentration range, greatly slows;culture growth for several generations. The growth rate progressively approaches and eventually exceeds the control rate. The individual cells of the early log population grow at the same rate as those in IAA but either are completely blocked from dividing or take . longer to divide. When these inhibited cells are washed and resuspended in control medium, the growth rate exceeds the control rate for three or four generations. Also, if inhibited cells from late log phase are resuspended in fresh medium containing IAA plus kinetin, they grow at a rate faster than the controls even in the presence of the chemicals. Although the fast-growing cells 
have a normal growth rate during interphase, they also continue to enlarge during the division period. This enlargement during division is caused by the premature initiation of daughter cell growth (before the completion of cytokinesis); in the inhibited cells the start of interphase is delayed.

In yeast, it was shown that kinetin does not serve as a source of purine, since it did not support growth of eight adenine-requiring mutants.

The observed increase or decrease in the time between mitosis and daughter-cell growth may, be ascribed to action on a gruwlyregulating system which is lduplicated at this stage of the cell cycle. It is postulated that ribonucleoprotein is the key component in this system, and there is evidence that kinetin may alter its metabolism.

Finally, the gruwlh of individual yeast cells.in a starvation medium was studied. The results were interpreted as showing the existence of this specific growth-regulating apparatus, which is duplicated, or doubles its activity, during cell division. This apparatus appears to consist of primary units which regulate the synthesis of secondary units which then regulate macromolecule synthesis. It appears that these secondary ones are not synthesized during nitrogen starvation. 
THE EFFECTS OF INDOLEACETIC ACID AND KINETIN

ON THE GROWTH OF SOME MICR OOR GANISMS

$$
\text { David.Kennell *† }
$$

Lawrence. Radiation Laboratory

and Donner Laboratory of Biophysics and Medical Physics University of California, Berkeley, California

March 31, 1959

\section{INTR ODUCTION}

Eighty years ago Charles Darwin. showed that some influence was transmitted from the upper to the lower part of seedlings exposed to one-sided illumination. This "influence" led to the observed bending of the plant. ${ }^{1}$ The concept of a hormonal regulation of growth originated almost a century ago with Julius Sachs in his pioneering studies of plant differentiation. However, it was forty years before Fitting began the research which culminated, through the efforts of Laibach, BoysenJensen, Paal, Went, and many others, in the quantitative measurement of the activity of various "auxins. "i"

Indoleacetic acid, IAA, (Fig, 1) is the most widely studied natural auxin and is found in most if not all plants as. well as in various animal tissues and urine. There are several recent reviews of the literature on auxins. $3,4,5$

Kinetin (Fig. 2) was first extracted from autoclaved or decomposed desoxyribosenucleic acid (DNA) samples. ${ }^{6}$ It was isolated as a substance which, in the presence of IAA, could cause normally nondividing tobacco pith tis sue to divide rapidly. 7

If significant and reproducible alterations in the growth of certain microorganisms could be shown; these would be ideal material to use for biochemical and genetic analysis of the systems involved. As is to be khown for both IAA and kinetin, no definite conclusions about their effect on the growth of microorganisms can be drawn from an examination of the literature. For convenience this introduction includes a concise discussion of the literature on each of these chemicals.

\footnotetext{
*Predoctoral Fellow, Public Health Service, National Cancer Institute.

${ }^{\dagger}$ Present address: Department of Bacteriology, Harvard Medical . : School, Boston, Mass.
} 
$-7-$

$\because \cdots$

$\because \therefore: \cdots$

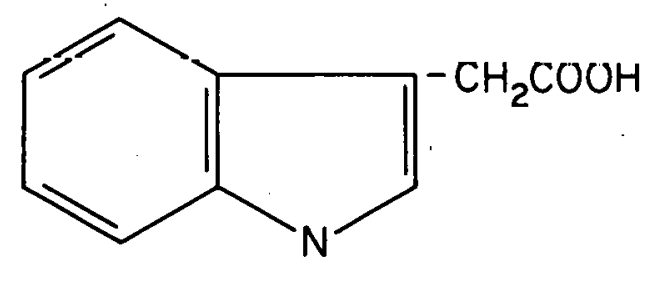

Indoleacetic acid

MU - 17082

Fig. 1. 


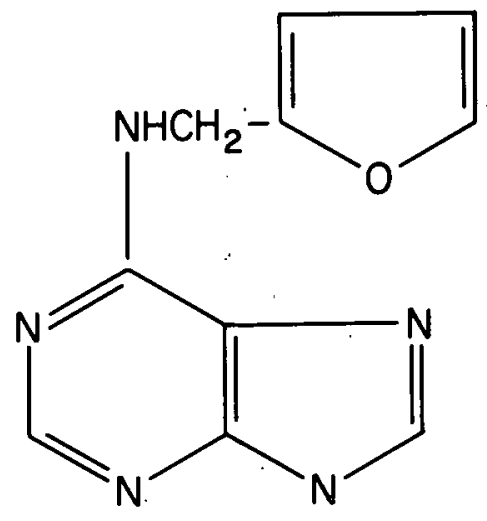

Kinetin

MU - 17082

Fig. 2 . 
Known Effects of Indoleacetic Acid on Plants

All auxins (as defined by Thimann) are organic substances which "... promote growth, i.e., irreversible increase in volume along the longitudinal axis, when applied in low concentrations to shoots of plants freed as far as practical from their own inherent growth-promoting substances. Auxins may and generally do have other properties, but this one is critical. ${ }^{8} 8$. Some of these other properties can be mentioned.

On a cellular level the first apparent action of auxin is to increase the rate of protoplasmic streaming. The promotion of cell division by auxin is generally limited to the cambial tissues in the spring. Auxin was first shown by Snow ${ }^{9}$, to be necessary for this activity although it probably acts in conjunction with other factors. Apical dominance of the top buds, which causes the lower buds to be inactive, is mediated via auxin. Cellular differentiation, such as the production of xylem tissue from parenchyma, occurs only in the presence of auxin. Auxins are involved in various other processes many of which.such as leaf abscission, are activated via a direct effect on cell elongation.

Known Effects of IAA on Microorganisms

$\underline{\text { Algae }}$

Chlorella has been studied, with conflicting results, since Yin first showed.an increase in average cell size of Chlorella vulgaris but little change in suspension density. 10 IAA concentrations of 1 to 10 $\mathrm{mg} /$ liter were used.

Pratt, 11 Brannon and Bartsch, ${ }^{12}$ and Brannon and Sel1 ${ }^{13}$ found rather large increases in growth rate and final cell concentrations of various Chlorella cultures, with. IAA concentrations ranging from 1 to $50 \mathrm{mg} / \mathrm{liter}$, but found $200 \mathrm{mg} / 1$ toxic. However, Roborgh and Thomas 14 . and Lhotsky ${ }^{15}$ found no effect of IAA from $20 \mathrm{mg} /$ liter to very low concentrations on growth rate or final cell concentration. Roborgh and Thomas agreed with Yin that there was cell enlargement of Chlorella, while the latter studied.twelve species of algae including Chlorella vulgari- 
Recently and.simultaneously, Bach and Fellig ${ }^{16}$ and.Street et al. 17 independently concluded that the reported increases in growth of various species of Chlorella were due to the alcohol used as a solvent for the auxin. From a careful examination of the various results the effects reported for ethanol do explain, in general, the earlier findings found with IAA but leave certain details unanswered. One is reminded of the classical controversy. over the existence or nonexistence of the Golgi Apparatus.

On other algae thexe are more conclusive reports. IAA stimulates growth of Euglena gracilis only when the organism is photosynthesizing in the presence of light but not of the non-chlorophyll-containing relative, Khawkinea halli. ${ }^{18}$ Likewise, the marine alga, Acetabularia mediterranea , is affected by IAA to an extent which is dependent again on the light intensity and also upon the season of the year. 19

$\underline{\text { Yeast }}$

First reports were by Nielsen, who in 1930 used rhizopin, which was later shown to be $\mathrm{IAA}$, from a Rhizopus fungus, in the broth medium used for brewer's yeast. ${ }^{20}$ He observed a twofold increase in dry mass as measured, apparently, in the stationary phase. He did not know the concentrations of IAA in the rhizopin extract.

The next major study reported no. effect of IAA on eight-species of yeast (not including baker's yeast) grown in synthetic medium with concentrations from $50 \mathrm{mg} /$ liter to $0.1 \mathrm{mg} / 1$ iter. 21

Following the German and French works, the third paper was by the Russian biologists, Kholodny and Beltiukova. ${ }^{22}$ They observed that in the light potato tubers become green and insusceptible to rotting bacteria, and simultaneously release phytohormone. Therefore, for practical agricultural reasons, they made an extensive study of the effects of auxins (corn-seed endosperm extracts or IAA) on a variety of bacteria as well as Saccharomyces cerevisiae. It was found that the yeast cultures showed decreased cell counts in log and stationary phases with the auxin extract. IAA at $30 \mathrm{mg} /$ liter to $2 \mathrm{mg} /$ liter produced larger cells, but the rate of population growth: was not measured. 
Loveless et al. , in a survey of the effects of chemicals on yeast and Escherichia coli bacteria, found that IAA at $5000 \mathrm{mg} / \mathrm{liter}$ in synthetic medium reduced the growth of Saccharomyces cerevisiae but did not affect its division .. 23 The method of measurement was crude and the concentration was high enough to be completely toxic.

The only metabolic studies with yeast have shown that IAA increases the fermentation rate of Saccharomyces cerevisiae ${ }^{24}$ in complete medium as well as the uptake of oxygen in low-glucose medium: 25

Fungi

Auxin, at fairly high concentrations, lowers the growth rate or inhibits growth in lower fungi, e.go, Phycomyces blakesleeanus, Aspergillus candidus, and Neurospora tetrasperma.

Bacteria

Escherichia coli suspensions were reported to reach twice the control stationary concentration when IAA at $0.1 \mathrm{mg} /$ iter to $1.0 \mathrm{mg} / \mathrm{liter}$ was present in the salts-glucose medium. ${ }^{2}$

However, Dubos reported inhibition of growth by IAA at 10 to 100 $\mathrm{mg} / \mathrm{l}_{2}$, in yeast extract-casein hydrolyzate medium, of Mycobacterium tuberculosis, Streptococcus haemolyticus, Streptococcus salivarius. and Shigella paradysenteriae. ${ }^{28}$ The inhibition was relieved by tryptophane at ten times the IAA concentration, indicating a competitive relation with the parent compound.

To determine if tryptophane-requiring bacteria are affected differently by IAA than the wild-type, various bacteria. were used. It was found that Aerobacter aerogenes cells which did not require the amino acid were the most strongly inhibited. This could mean an interference with the synthesis of tryptophane. Escherichia coli, Lactobacillus caseii, Lactobacillus arabinosus, Streptococcus faecalis, and Aerobacter aerogenes were all inhibited in growth by $1000 \mathrm{mg} / \mathrm{liter}$ 


\section{$-12$}

IAA, but no stimulation of.E. coli growth at the levels reported by Ball was found. 29 The competition of IAA with tryptophane may not be related to its action as an auxin. On the other hand, the fact that tryptophane competes with.IAA in these cells does not mean that IAA is not performing a specific function other than substituting for the amino acid.

To add another contradiction, Loveless et al. in the previously mentioned work ${ }^{23}$ found no inhibition of E. coli growth at the high concentration of $5000 \mathrm{mg} /$ liter IAA.

\section{Conclusions from Known Efferts of IAA}

It can be seen that there is a wide divergence of results for the responses reported with.a given organism. These may be explained from such considerations as:

a. The age of the culture when the chemical is added and when the growth is measured.

b. The duration of the chemical's presence.

r. The use of undefincd media and a narrow range of concentrations. A complete experiment should include the effect on all three stages of culture growth: lag time, logarithmic growth rate, and final population density. Actually none of the papers mentioned told of specifically measuring the rate of growth, which is probably the only variable of physiological significance for thestudy of a particular factor on the growth processes of a cell. The lag time alone is primarily a reflection of the adaptability of the cell and the medium to each other, while the stationary cell concentration is an indication of the ability of the medium to support the growth of a particular cell. Both of these are under the influence of a wide variety of chemical and physical factors, most of which have little relation to metabolic processes specifically associated with growth except in:: sorfar as they affect the cells at the particular stage. 
Except for reports of the effects on the glycolysis and respiration of liver slices ${ }^{30}$ the biological action of IAA appears restricted to plant tissues and the primitive microorganisms. There is a conspicuous absence of positive reports on protozoan and metazoan cells even though IAA has been extracted from various animal sources. This could be due to real physiological differences between plants and animals, or to. the difficulty of obtaining controlled growth environments for protozoans in order to assay the effects of a chemical. Tetrahymena pyriformis is the only ciliatc that can bo grown in a shemirally defined medium.

Nevertheless, the result has been to initiate many theories of auxin action which have had as their basis a consideration of the characteristics of plant rell.grnwth, e. g; ; the uptake of water durirgif cell elongation:

\section{The-Discovery of Kinetin}

From extensive callus and stem tissues cultured in vitro, it was found that there was a quantitative balance between. IAA, adenine, and various other substanccs. 31 It was further shown that this was not due to a competitive relationship between auxins and purines. ${ }^{32}$ Likewise, pith tissue could be induced to divide in the presence of IAA only if vascular tissue was near by to allow the diffusion of substances to pith. ${ }^{33}$ In a search for an IAA-purine complex it was found that a factor from aged DNA samples of herring sperm could substitute for the vascular tissue. ${ }^{7}$ This compound was named kinetin because it induced rapid cell division in the inert pith cells. Since then various effects have.been reported, but this introduction considers the studies which have shown a direct action on growth and cell division of plant and animal material. Some of the other effects are considered in the section covering the possible mechanisms of action. 
Skoog's group has made further studies aimed at understanding the nature of the stimulation in tobacco pith tissue. ${ }^{34}$.Using microspectrophotometric analysis of Feulgen-stained preparations, they concluded that "in pith tissue kinin is required for mitosis and cytokinesis, and possibly DNA doubling, and that auxin is necessary for DNA doubling and mitosis."

\section{Known Effects of Kinetin}

A Polish group has made a rough but comprehensive survey of the effects of kinetin on various animal and plant materials. 35,36 Kinetin, given subcutaneously to mice (50 to $100 \mathrm{mg} / \mathrm{kg}$ weight), inhibited hair growth.in the region of the injection, and caused premature oestrus in females and spermatogenesis in males, as well as increased numbers of erythrocytes in the circulation. Frog tadpoles were reported to grow faster in solutions of $10^{-8} \mathrm{~g} / \mathrm{ml}$ of kinetin. Baker's and brewer's yeast had higher cell concentrations after 24 to 48 hours (presumbly stationary phase) with.concentrations of kinctin between $10^{-5}$ and $10^{-9} \mathrm{~g} / \mathrm{ml}$, while three strains of bacteria were not affected. The results with yeast were not found in my experiments. Various protozoans had increased cell numbers at the end of 6 days: Paramecium caudatum, Ochromonas malhamensis, and Euglena gracilis.

Another group later found that the generation time of Paramecium caudatum was sensitive to a range of kinetin concentrations from $5 \times 10^{-7} \mathrm{~g} / \mathrm{ml}$ up. ${ }^{37}$ The maximum positive promotion was at a concentration which agreed with that of the Polish.work $\left(10^{-7} \mathrm{~g} / \mathrm{ml}\right)$.

The regeneration of Hydra was found to be inhibited by kinetin, 38 as also was that of anucleate, nucleate, or whole Acetabularia fragments. 39

Ogawa reported an increased mitotic rate of Yoshida sarcoma cells transplanted into rats, ${ }^{40}$. while Lettre and Endo reported negative results on various. mammalian cells in the presence of kinetin. 41

Kinetin and other 6-substituted purines augment the growth inhibition of pteridine-inhibited Lactobacillus arabinosus cells. 42 
These authors propose the hypothesis that kinetin suppresses the synthesis of thymidine. This implies a direct role in DNA synthesis. However, the results with a particular mutant should be generalized with caution.

\section{Conclusions from Known Effects of Kinetin}

1. Kinetin, as opposed to IAA, has been shown to modify the growth of several animal cells.

2. The fact that other purine compounds, including exogenous adenine itself, exhibit activity in several of the systems studied points to a purine-containing compound in the cell which can be modified.ur inlibited from formation or activity by a certain class of compounds which may include adenine itself.

3. It is interesting that in some cases kinetin requires the presence of exogenous IAA (tobacco pith tiissue, yeast, callus tissue of pea root), whereass in others it does not (bacteria, Paramecium, Hydra, sarcoma cells; Acetabularia). This difference may be illusory. It may be due to variation of endogenous levels of IAA, or differences in the ability of some cells to metabolize, the compound. A good example is from experiments being done on pea root tissue. Torrey ${ }^{43}$ and Jensen ${ }^{44}$ have found that dividing meristematic tissue, which contains endogenous $1 \mathrm{AA}$, is inhibited by kinetin alone. However, near-by nondividing callus tissue, which contains no internal auxin, requires IAA plus kinetin to be stimulated to divide.

4. There have been no really detailed studies made on the quality or magnitude of the response of a particular organism to either of these chemicals in a well-defined medium. 


\section{Purpose of These Experiments}

The following experiments were done to understand the type of physiological response of one cell $r$ ather than to sample a large number of cells. Perhaps the conclusions drawn from one or two cells which are based on accurate results can then be extended to other cells and tissues.

Microorganisms are excellent test material for the study of physiological processes for a number of reasons. They are generally fast-growing, relatively homogeneous populations, and have genetical and biochemical characteristics which are quite well known.

In particular, the yeast cell was chosen for more detailed study because of the very large and reproducible effects of both compounds on the growth of yeast suspensions.

From the preceding review of the studies made with IAA and with kinetin as well as from the experiments to be reported, it can be seen that inhibition of growth or cell division is as common as its augmentation when these chemicals are used on biological material. It has long been known that auxin can either stimulate or inhibit the main types of plant growth--bud formation, stem elongation, and root development--depending on the concentrations used. ${ }^{45}$ Not only is the concentration of growth factors critical but also the presence or absence of tother chemicals such as adenine can obscure or reverse the effect.

Modern concepts of the regulation of growth and differentiation emphasize quantitative relationships between various physical and chemical. substances in determing the type of response of the organism (for further discussion, see Skoog and Miller. ${ }^{46}$ ) This is contrary to the classical concept of specific organ-forming hormones, but it does not detract :..... from the importance of specific growth.substances; it merely stresses the importance of the interactions between them. For example, kinetin has been shown to counteract the inhibition of bud development by auxin, according to a recent study of apical dominance in iwhole plants. ${ }^{47}$ Skoog and Miller, working with tobacco callus tissue in vitro found that there 
is a delicate balance between IAA, kinetin, various amino acids, and other factors in the control of bud formation. 46 In the experiments on yeast reported here, kinetin and IAA seem to be acting synergistically to cause inhibition of growth of the yeast cultures.

Therefore; it is not surprising that kinetin increases the cell-. division rate for some cells but reduces it for others. The difference is undoubtedly due to the presence of different levels of endogenous. auxin, inactivating enzymes, vitamins, etc. in different cells. Also, augmentation of a particular process in a cell can either be a benefit or a: detriment to its survival or rate of growth, depending on the limiting factors. This: latter point is discussed again in the consideration of mechanisms of kinetin action. 


\section{PROCEDURES, RESULTS AND CONCLUSIONS}

\section{Amoeba proteus}

Methods and Materials

Single cells from a common clone were placed in $1-\mathrm{cm}$ petri dishes.containing amoeba medium described by Prescott. 48 The food organism was the ciliate, Tetrahymena pyriformis, which was grown, by use of sterile technique, in $2 \%$ proteose-peptone and washed by centrifugation before addition to the amoebae about every two days. Amoeba cells were not maintained in sterile solution, although the bacterial population was kept low by the ciliate. However. Amoeba cells were transferred by a micropipet to fresh medium every two days. The number of cell divisions was followed by counting individual cells every day under a dissecting microscope. The experiments were performed at $19^{\circ} \mathrm{C}$, at which the normal generation time is about 36 hours, and also at $14^{\circ} \mathrm{C}$, at which it is several days.

\section{Effects of IAA and Kinetin on Growth in Amoebae}

The first organism studied Amoeba proteus, a single-celled animal which has been a favorite object of investigation by cell physiologists since the last century. It was found that kinetin at $10^{-6}$ $\mathrm{g} / \mathrm{ml}$ increased the rate of cell division slightly over the control rate. Concentrations used were between $5 \times 10^{-6} \mathrm{~g} / \mathrm{ml}$ and $1 \times 10^{-6} \mathrm{~g} / \mathrm{ml}$, with the best results at $10^{-6} \mathrm{~g} / \mathrm{ml}$. A typical experiment is shown in Fig. 3.

IAA at $10 \mathrm{mg} /$ liter produced no change in cell counts nor did: adenosine at $10^{-6} \mathrm{~g} / \mathrm{ml}$ IAA plus kinetin was not tested.

The significance of the results with kinetin alone can be tested by using simple tests for standard deviation. There were nine separate experiments with kinetin alone, such as that shown in Fig. 3. The: total numbers: of cells: at the start and at the end of each experiment 


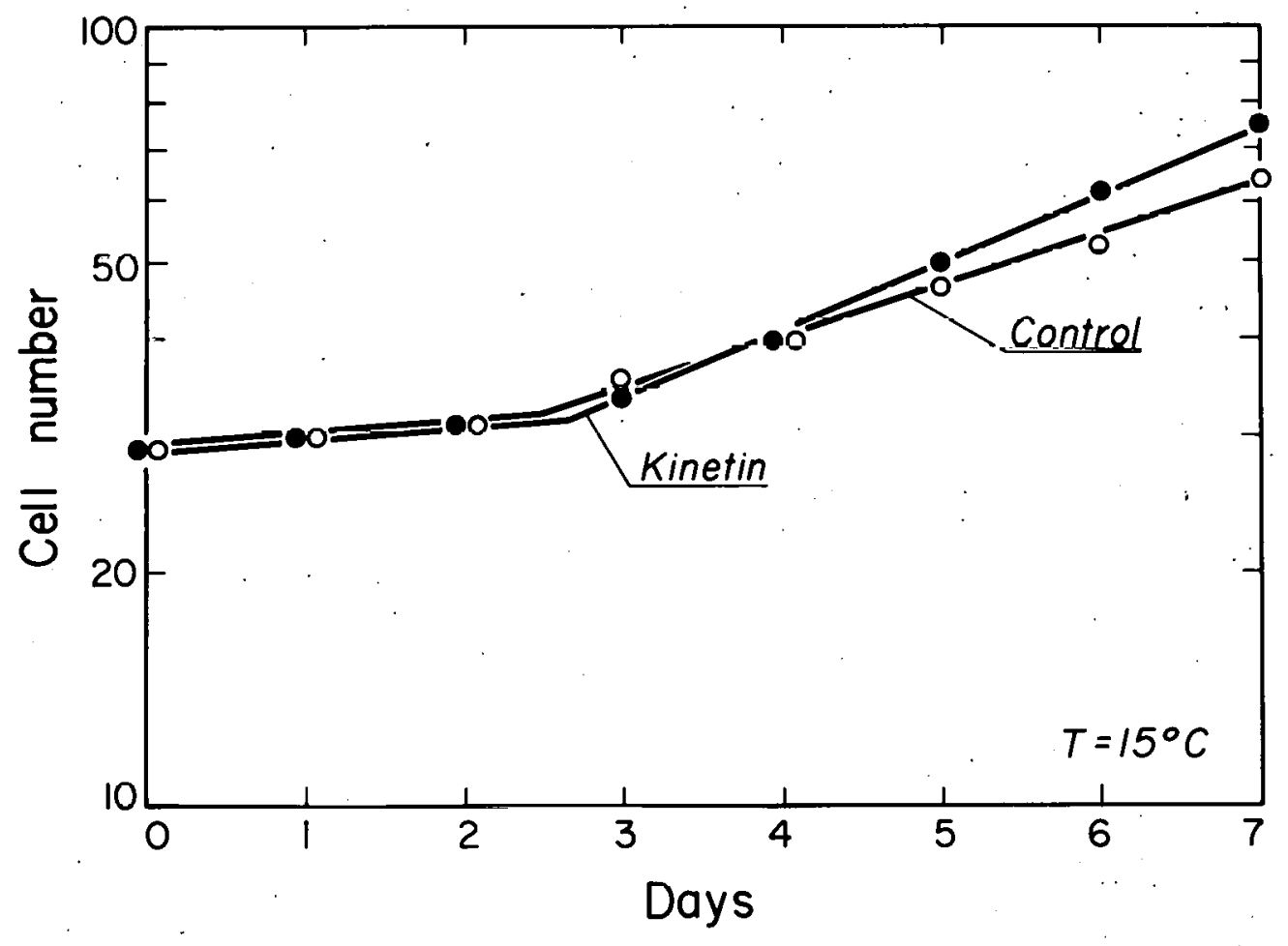

$\mathrm{MU}-16390$

Fig. 3. A logarithmic plot of the number of Amoeba proteus cells on successive days in the presence'of kinetin at $10^{-6} \mathrm{~g} / \mathrm{ml}$. Control cells are cultured in amocba medium with no added compound. 
are presented in Table I. The length of time for each experiment and the temperature used are given. In order to test the significance of the results, it is necessary to consider the cell number for each day, since the end of each experiment was arbitrarily decided. A simple standard-deviation test can be used. Let the ratio of the total number of cells in the dishes containing kinetin to the total number of control cells for any experiment on any given day of the experiment be used as a measure of the effect of the chemical on the cell number. (Thus, 1.0 would: mean "no effect. ") There are 9. experiments, covering 39. "experiment-days" (excluding day zero). The average ratio for all these experiment-days is 1.13 , which represents a $13 \%$ increase. The standard deviation is

$$
\sigma_{m}=\sqrt{\frac{d^{2}}{n}}=0.164
$$

and the standard deviation of the mean is

$$
\sigma_{\mathrm{m}}=\frac{\sigma}{\sqrt{\mathrm{n}-1}}=\frac{0.164}{6.16}=0.0266 .
$$

Here $d$ is defined as the difference between 1.13. and the ratio for a certain day of a given experiment, and $n$. is the total number of experiment-days, which was 39 . Thus, $68 \%$ of the experiment-days should give ratios of $1.13 \pm .03$. This is statistically significant, and indicates that the duration of the experiment was not critical.

Therefore, it is concluded that kinetin by itself, and at the concentration used, decreases the generation time of Amoeba proteus cells.

To test the effect on the food organism Tetrahymena pyriformis, growth curves with and without kinetin at $10^{-6} \mathrm{~g} / \mathrm{ml}$ in $2 \%$ proteosepeptone were determined;aihaemacytometer chamber was used to count the cells. There was no observable change in growth rate. 
Table I

Effects of kinetin on generation time as indicated by number of cells, for Amoeba proteus.

\begin{tabular}{|c|c|c|c|c|c|c|c|c|c|c|}
\hline \multirow[t]{3}{*}{ Experiment } & \multirow[t]{3}{*}{ Temp $\left({ }_{C}\right)$} & \multirow{3}{*}{$\begin{array}{l}\text { Duration } \\
\text { Exp (Days) }\end{array}$} & \multicolumn{5}{|c|}{ NUMBER OF CELLS } & \multirow{2}{*}{\multicolumn{3}{|c|}{$\begin{array}{l}\% \text { Incr ease } \\
{ }^{\Delta_{K}}{ }^{-\Delta_{C}} \times 1 \infty 0\end{array}$}} \\
\hline & & & \multicolumn{3}{|c|}{ CONTROL } & \multicolumn{2}{|c|}{ KINETIN } & & & \\
\hline & & & Start & End & $\Delta \mathrm{C}$ & Start & End & $\Delta \mathrm{K}$ & $\Delta_{\mathrm{C}}$ & \\
\hline 1 & 15 & $\because 4$ & 24 & 34 & 10 & 24 & $41:$ & 17 & 70 & \\
\hline 2 & 15 & 7 & 29 & 64 & 35 & 29 & 75 & 46 & 31 & \\
\hline 3 & 14 & 6 & 14 & 28 & 14 & 14 & 33 & 19 & 36 & \\
\hline 4 & 13 & 2 & 55 & 57 & 2 & 63 & 72 & 9 & $\because 350$ & \\
\hline 5 & 19 & 5 & 12 & 46 & 34 & 12 & 77 & 65 & 91 & 1 \\
\hline 6 & 19 & 2. & 23 & 31 & 8 & 23 & 39 & 16 & 100 & $\stackrel{2}{1}$ \\
\hline 7 & 19 & 3 & 32 & 122 & 90 & 37 & 153 & 116 & 29 & \\
\hline 8 & 19 & 4 & 41 & 63 & 22 & 40 & 59 & 19 & -14 & \\
\hline 9 & 19 & 3 & 8 & 13 & 5 & 8 & 19 & 11 & 120 & \\
\hline
\end{tabular}




\section{Escherichia coli Bacteria (strain B)}

Methods and Materials

Cells were stored at $4^{\circ} \mathrm{C}$ on agar slants consisting of $2 \%$ Bacto Nutrient Agar (Difco). The experimental growth solutions (long been used in these laboratories) contained $\mathrm{Na}_{2} \mathrm{HPO}_{4} \cdot 7 \mathrm{H}_{2} \mathrm{O},(5.94 \mathrm{~g})$, $\mathrm{KH}_{2} \mathrm{PO}_{4}(4.54 \mathrm{~g}), \mathrm{MgSO}_{4} \cdot 7 \mathrm{H}_{2} \mathrm{O}(0.433 \mathrm{~g})$, NaCl : $(0.5 \mathrm{~g}), \mathrm{NH}_{4} \mathrm{Cl}(1.0 \mathrm{~g})$, glucose $(4.0 \mathrm{~g}), 1000 \mathrm{ml}$ distilled $\mathrm{H}_{2} \mathrm{O}$. The glucose was autoclaved separately. Cultures were maintained under aeration in test tubes which were immersed in a $37^{\circ}$ bath. For a given experiment, log phase cells from a 12 -hr culture were inoculated into control and experimental tubes to the same final cell density. This was approximately $5 \times 10^{3}$ cells per.ml. The control generation time was approximately 50 minutes under these conditions. Growth was measured by turbidity on a Beckman DU Spectrophotometer at $650 \mathrm{~m} \mu$ and viability by plate count.

The radioactivity of the bacterial cells in the isotopic-competition experiment was determined. The cells were washed five or six times by fast centrifugation in distilled water to remove any traces of isotope from the medium, and $0.1-\mathrm{ml}$ portions of the washed suspension were pipetted onto aluminum planchets, dried in air, and counted in a gas-flow counter. The specific activity is here defined as the activity per unit mass of bacterial cells and was obtained by

(Activity per $\mathrm{ml}$. cells) / (Calibrated turbidity reading) The specific activity has no importance except for relative measurements. Effects of Kinetin on Growth in Bacteria

Escherichia coli bacteria cultures in a salts-glucose medium show an accelerated growth rate when kinetin at $10^{-6} \mathrm{~g} / \mathrm{ml}$ is present (Fig. 4). In this minimal medium, adenine--which serves as a control compound-also promotes growth. From previous studies on the nutritional requirements of this cell, it is known that adenine serves as a source of 


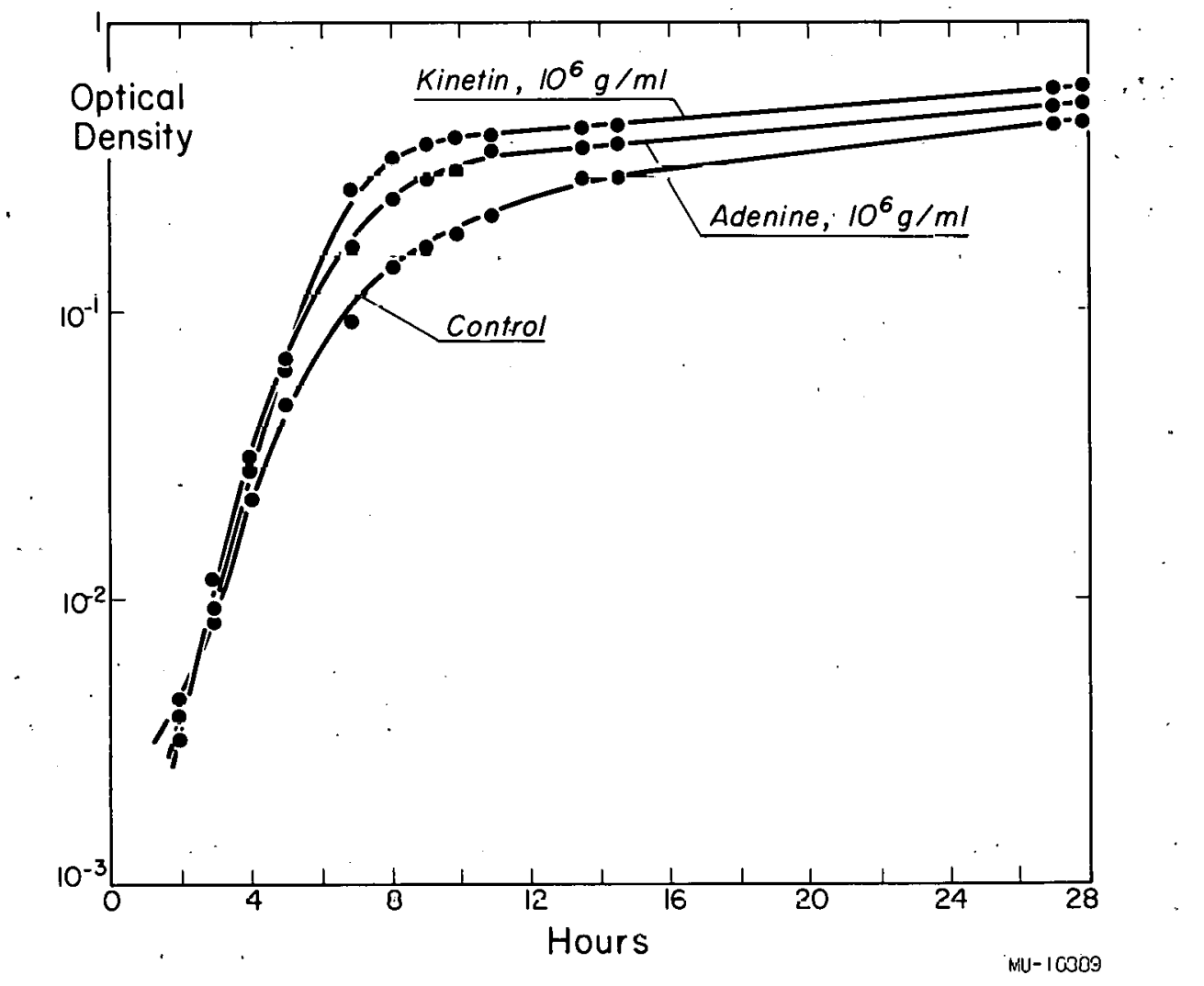

Fig. 4. Growth of Escherichia coli bacteria in the presence of kinetin $\left(10^{-6} \mathrm{~g} / \mathrm{m}\right)$, in the presence of adenine $\left(10^{-6} \mathrm{~g} / \mathrm{ml}\right)$, and with no addition. Growth is measured by a calibrated optical density. (All cultures reach the same final culture density.) 
nucleic acid purine (about $90 \%$ goesinto the nuclei acids). 49 Although the curves were similar in general, there were reproducible differences in growth of the bacterial cultures in the presence of kinetin or adenine: the kinetin-containing suspensions had a longer lag time but grew at a faster rate to reach the same final cell concentration.

The Relation of Kinetin to Adenine

Therefore, an experiment was done to determine if this difference was real on the biochemical level. Specifically, one would like to know if kinetin is being hydrolyzed to adenine and thus merely serves as a purine source for E.coli. If this were true, then it should compete with the parent compound for uptake by the cell. This was tested by using $\mathrm{C}^{14}$-adenine as a marker and comparing the specific activity of one growth flask containing the labeled adenine plus nonlabeled adenine to a second flask containing $\mathrm{C}^{14}$-adenine and kinetin. The concentrations of $\mathrm{C}^{1.4}$ - adenine were the same in each flask as were those of the unlabeled compounds.

The curves show that at no time during growth of the cultures was it possible to observe competition between kinetin and $\mathrm{C}^{14}$-adenine (Fig. 5). In other words, while $\mathrm{C}^{12}$-adenine competes with $\mathrm{C}^{14}$-adenine in an equivalent way, kinetin does not reduce the specific activity of the cells. The curves follow the general shape expected: a rapid increase during the dilution of the original nonlabeled cells followed by a level region of maximum labeling and then a logarithmic decrease when the $\mathrm{C}^{14}$-adenine is depleted and the labeled cells become diluted.

If kinetin did not compete with adenine, the increase in specific activity for the experiment whose curve is shown would theoretically be $65.3 \%$ before the period of logarithmic decrease, as computed from the relationship

$$
\begin{aligned}
& \frac{\text { activity in kinetin flask per unit mass }}{\text { activity in adenine flask per unit mass }} \\
& =\frac{0.027 \mathrm{mg} \mathrm{C} \text {-adenine } /\left(0.027 \mathrm{mg} \mathrm{C}^{14} \text {-adenine }+0.108 \mathrm{mg}\right. \text { adenine) }}{0.027 \mathrm{mg} \mathrm{C}^{14} \text {-adenine } /\left(0.027 \mathrm{mg} \mathrm{C}^{14} \text {-adenine }+0.196 \mathrm{mg}\right. \text { adenine) }} \\
& =\frac{1.65}{1.00} .
\end{aligned}
$$




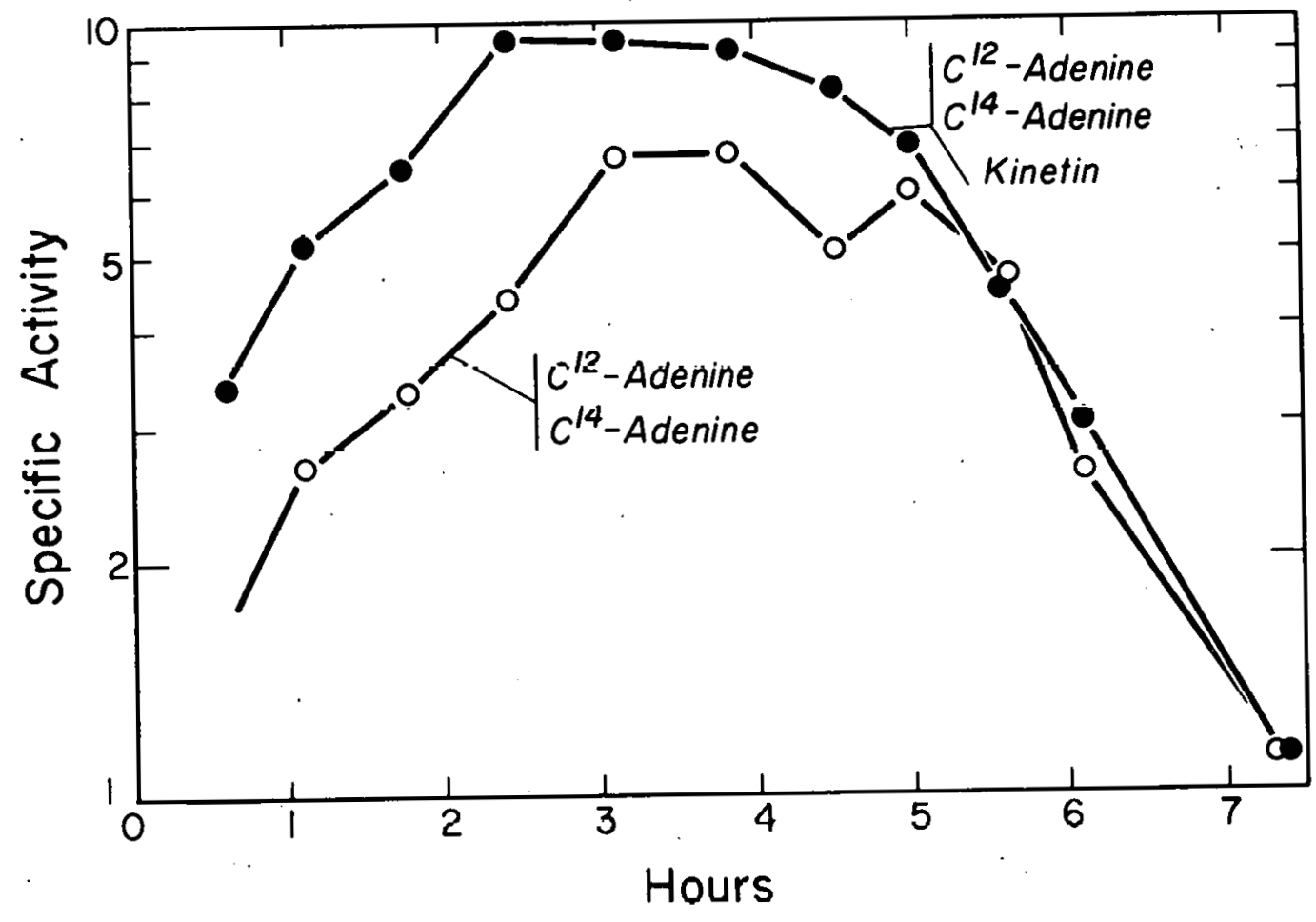

MU - 16388

Fig. 5. The specific activity. (counts per unit mass of cells) in flasks containing $\mathrm{Cl}^{14}$-adenine plus $\mathrm{C}^{12}$-adenine and Cl4-adenine plus kinetin. Between Hour 2 and Hour 3 the initial inoculum of nonlabeled cells has become insignificant compared with the new labeled cells. At. Hour 5 the $\mathrm{C}^{14}$-adenine is depleted and further divisions produce nonlabeled cells. 
(Since the important variable: is the ratio of labeled to unlabeled $\therefore$ adenine; the molar: concentration of neither adenine nor kinetin. is required.). The first seven experimenta lopoints gave an average increase of $59.3 \%$, which is remarkably close to the theoretical increase, in consideration of the possible loss of activity with extensive washing. The experiment was repeated, using different ratios of labeled to unlabeled adenine, with the same result (see Table II).

Therefore it is concluded that no major competition exists between kinetin and the parent compound, adenine, in the bacterial cell. This is important, since one can conclude that kinetin is not being used in the bulk of the adenine-containing material of the cell. This does not exclude the possibility that it is acting as an analog to a specific compound which is a derivative of adenine.

\section{Yeast}

Methods and Materials

Saccharomyces cerevisiae (S. c) (strain X495), a budding yeast, and Schizosaccharomyces pombe (S.p.) (strain NCYC 132), a fission yeast, were stored on yeast extract-dextrose agar at $4^{\circ} \mathrm{C}$. A few preliminary experiments with kinetin alone were done in a complete broth medium of $2 \%$ yeast extract, $4 \%$ glucose, and $0.5 \% \mathrm{KH}_{2} \mathrm{PO}_{4}$, the glucose being autoclaved separately. All other experiments (except in starvation media) were done in a complete synthetic medium containing only compounds necessary for the normal growth of yeast (Wickerham's synthetic medium, U.S. Dept. Agric. Techn. Bull. No. 1029:1951):(Difco "Yeast Nitrogen Base"). Inositol at $10^{-4} \mathrm{~g} /$ liter, which. is a requirement for $\mathrm{S}_{\text {. }}$. , was added when this cell was being studied. This medium, which contains several vitamins and inorganic salts as well as some amino acids, was filtersterilized along with glucose which is used as a carbon source. (This medium was prepared at $10 \mathrm{x}$ strength and stored at $4^{\circ} \mathrm{C}$.). Cultures 
Table II

Isotopic competition: differerces (in \%) between specif-c activities in sultures grown with kinetin and in cultures grown with a denine

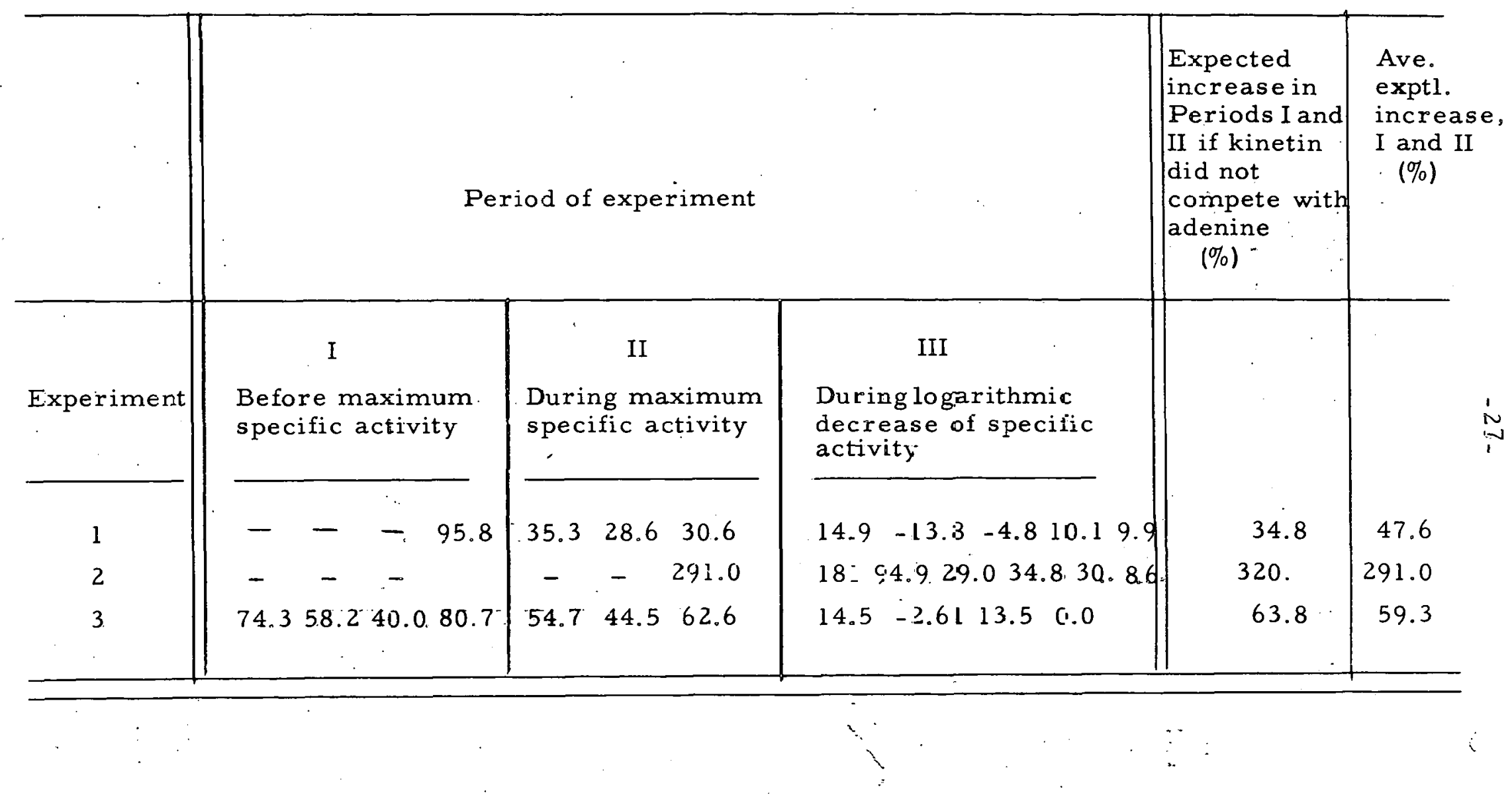


were grown in Erlenmeyer flasks with vigorous shaking or swirling (no special aeration). The flasks were maintained at $30^{\circ} \mathrm{C}$, which is optimal for these yeasts. For a given experiment, log-phase cells from a YED agar plate, which had been streaked about 24 hours previously for S. p. or 12 hours for S.C., were collected on a loop and suspended in about $1 \mathrm{ml}$ of distilled water to the desired concentration. A volume of $0.1 \mathrm{ml}$ of these cells was inoculated into each of the flasks. The inoculum was usually about $2 \times 10^{5} \mathrm{cells} / \mathrm{ml}$. Growth was measured by turbidity on a Beckman DU Spectrophotometer at $650 \mathrm{~m} \mu$. Viability was determined by plate count. Total cell counts were made by direct counting in a clinical haemacytometer.

The volume of individual S. p. cells was determined with an eyepiece micrometer after the method described by Mitchison, except that in my experiments the cells were grown in liquid instead of agar. An aliquot of approximately $0.5 \mathrm{ml}$ of the culture whose cells were to be observed was pipetted onto the elevated portions and channels of a clinical haemacytometer with coverslip. When the haemacytometer was floodcd this way, gruwing cells were stationary on the elevated grid and could be observed for 5 hours without drying (or, if necessary, additional suspension from the original culture could be added indefinitely without disturbing the cells under observation). Growth remained normal for at least 8 hours (the longest interval followed), judging from the constancy of the generation time. Since the width of the cell remains constant during growth, the volume is directly proportional to the length. Hence, the error in the volume measurement is directly proportional to the error in the length measurement, which in these studies was $\cdots$ maximum when the cells has just divided but was never more than ?" about $8 \% . . . . ; \ldots$. .

(To avoid confusion from the term "growth," individual cell growth" will always refer to volume growth of the individual cell (unless otherwise stated). "Culture growth, "of course, concerns the increase in protoplasmic mass in a suspension of millions of microorganisms.) 


\section{Effects of IAA on Culture Growth in Yeast}

The logarithmic growth rate of suspensions of Schizosaccharomyces pombe (abbreviated here S. p.) or of Baker's yeast, Saccharomyces cerevisiae (abbreviated here $S_{0} c_{0}$ ), is decreased by the addition of IAA over a range of concentrations $-0.02 \mathrm{mg} /$ liter to $20 \mathrm{mg} /$ liter; $160 \mathrm{mg} /$ liter is toxic $(\mathrm{Fig}$. 6). The difference in the growth curves is due to growth rate only; the lag-phase time and final cell concentration are the same as the controls. This is not in agreement with Kholodny and Beltiukova, who found a reduced final cell concentration. 22 Different growth conditions (such as media used), may account for this. The conlrul generation time at $30^{\circ}$ of S. p. in synthetic medium is 2 hours 50 minutes. With IAA at $20 \mathrm{mg} / 1$ ter it is very cluse to 4 hours throughout the log phase. These times do not differ by more than 15 minutes from experiment to experiment. The generation time, as measured by total cell count or viability, agrees with that found from turbidity measurements. The fact that the fraction of cells which are viable in the IA:A cultures does not increase markedly during exponential growth rules out the determination of the final curve by a process of selection, whereby only a very few cells in the inoculum grow at the control rate and the rest are inviable. This point is shown more detintively by the individual-cell studico to be discusser.

\section{Effects of Kinetin on Culture Growth in Yeast}

The addition of kinetin by itself to synthetic medium or yeast extract-dextrose broth produces no reproducible change in the growth curves uf $\underline{G}_{\text {. p. }}$ or S. c. cultures. There may be a slight decrease in the lag time but it is not significant.

However, in the presence of various concentrations of IAA, kinetin produces a marked decrease of the growth rate below that with IAA alone (Fig. 7). For each of the above-mentioned IAA concentrations, kinetin was added in a wide range of values $\left(10^{-5} \mathrm{~g} / \mathrm{ml}\right.$ 


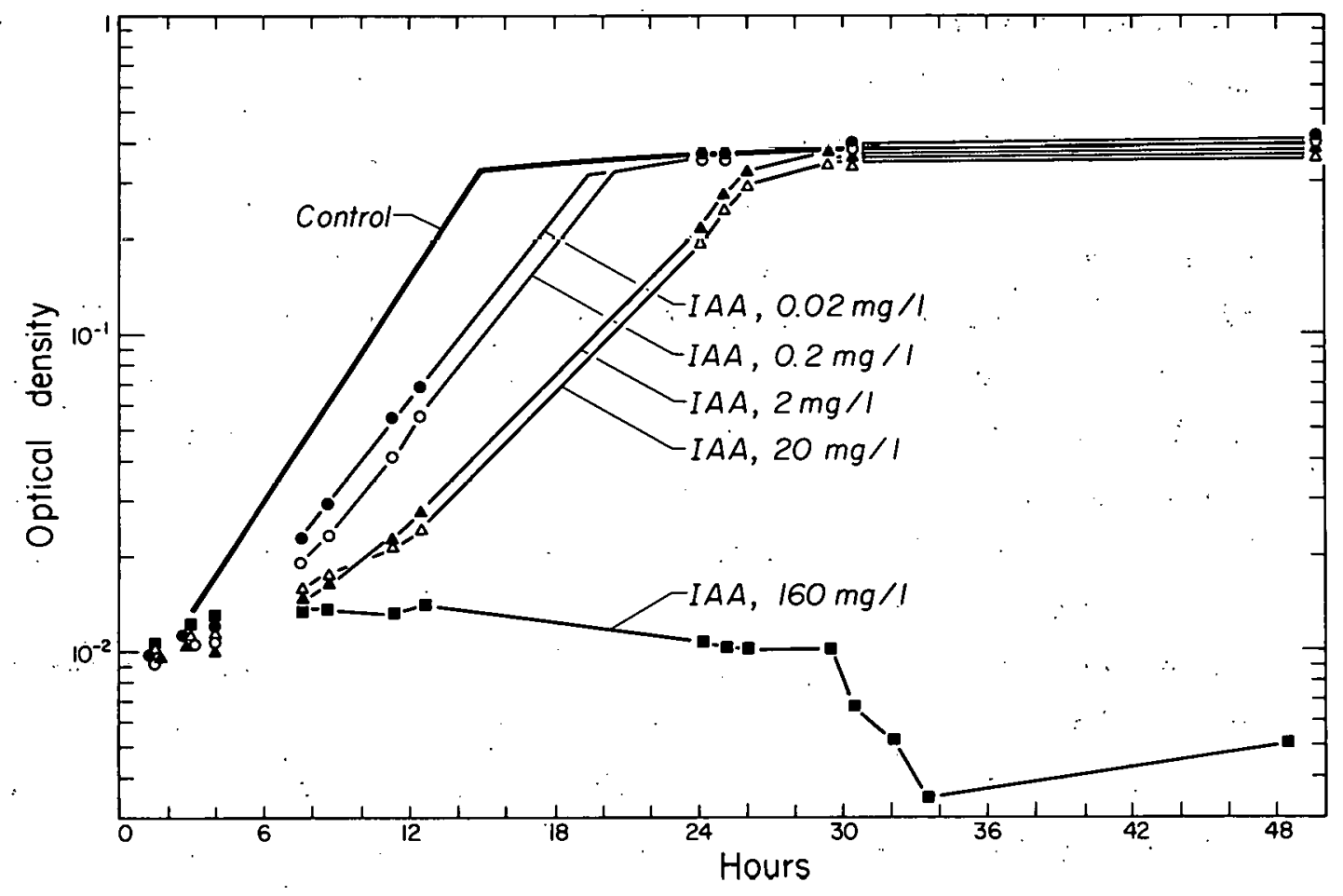

MU -17089

Fig. 6. The effect of various concentrations of IAA on the culture growth of S. p. cells in synthetic medium. Growth is measured by optical density. 
to $\left.10^{-12} \mathrm{~g} / \mathrm{ml}\right)$. The lowest level of kinetin to give a marked response was at $10^{-11} \mathrm{~g} / \mathrm{ml}$, which gave the maximum inhibition for the series of concentrations of IAA at $20 \mathrm{mg} /$ liter.

There is a synergistic relation between IAA and kinetin. For maximum inhibition the lower the concentration of: one, the higher the concentration of the other has to be (Fig. 8). Figure 9 shows that at a very low IAA concentration kinetin has no effect even at the highest kinetin concentrations used.

The rate of growth in the presence of the two chemicals is not linear on a log plot but approaches or even exceeds the control rate after several generations. Furthermore, the cells are almost twice as heavy as control cells at the start of the log phase, when the inhibition, is greatest, but become progressively lighter to approach control weight as the effect lessens during log growth. (Table III and Fig. 7). The cell weight here is the average dry weight per cell of a population of millions of cells. For better understanding of the increased mean mass per cell, accurate volume measurements were made of approximately .150 control cells and cells from cultures with IAA-plus kinetin in early log growth:. "Giant" cells which have marked morphological abnormalities were found in the treated cultures. The increased size is due to an increase in width but not often in length. The high values for the average mass per cell in these suspensions can be accounted for by the presence of these giants, which causes a proportional increase in average volume per cell. The IAA-pluskinetin cells are heavier, not due to an increase in density, but rather to a real increase in size of a proportion of the population.

As far as could be determined by individual cell studies, these giant cells were inviable. Furthermore, they apparently were not formed to any extent in log phase but during the lag phase, so that they became diluted out of the population as multiplication progressed. 


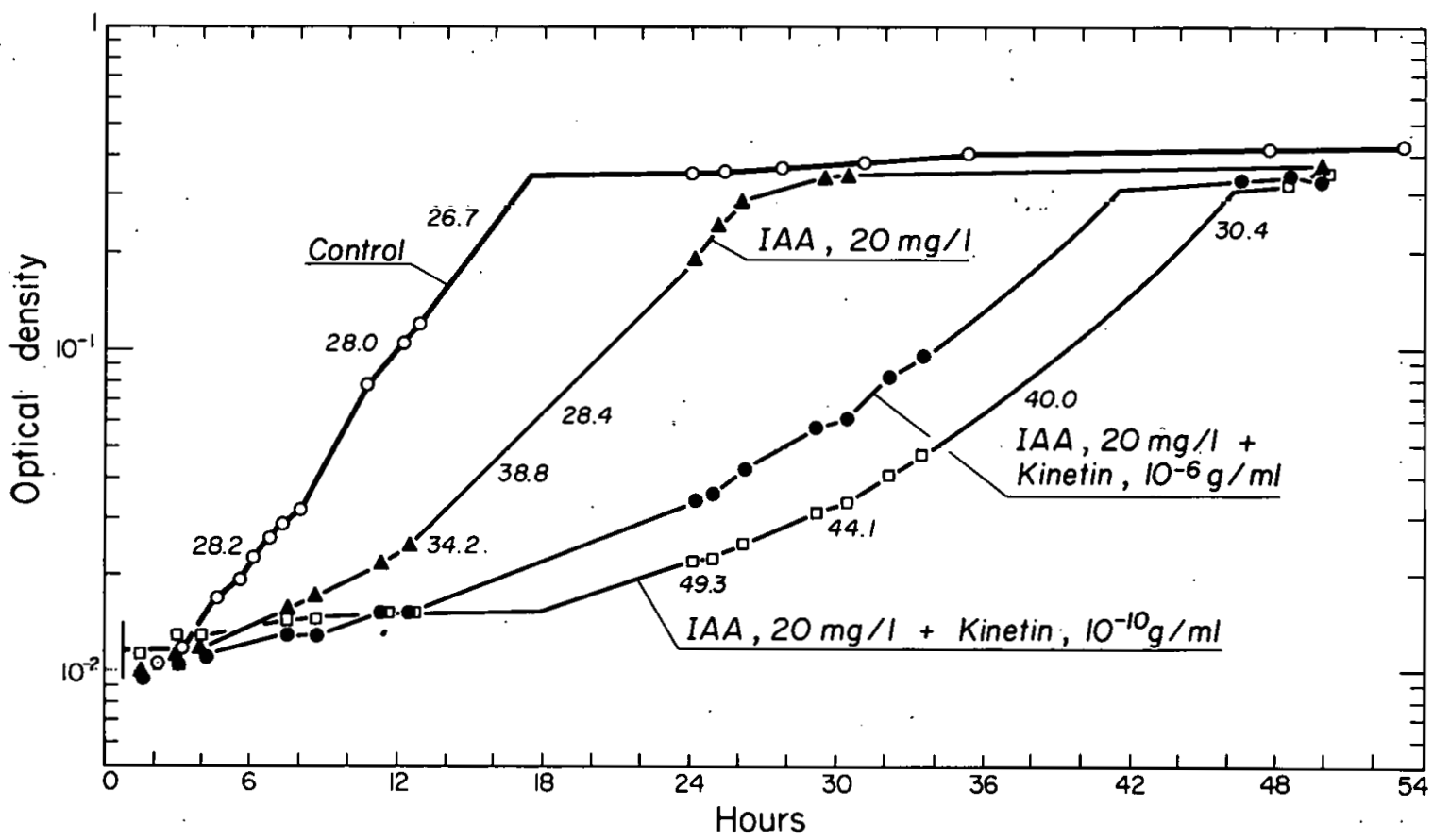

MU -17087

Fig. 7. The effect on culture growth of a relatively high and a very low concentration of kinetin added to a particular concentration of IAA ( $20 \mathrm{mg} / \mathrm{l})$. Growth is measured by optical density: If there had been a smaller.initial inoculum, the gradual increase of the growth rate to equal or exceed the conusl rate would be shown. The numbers along the curves represent the average dry weight per cell in the culture at that stage of culture growth. 


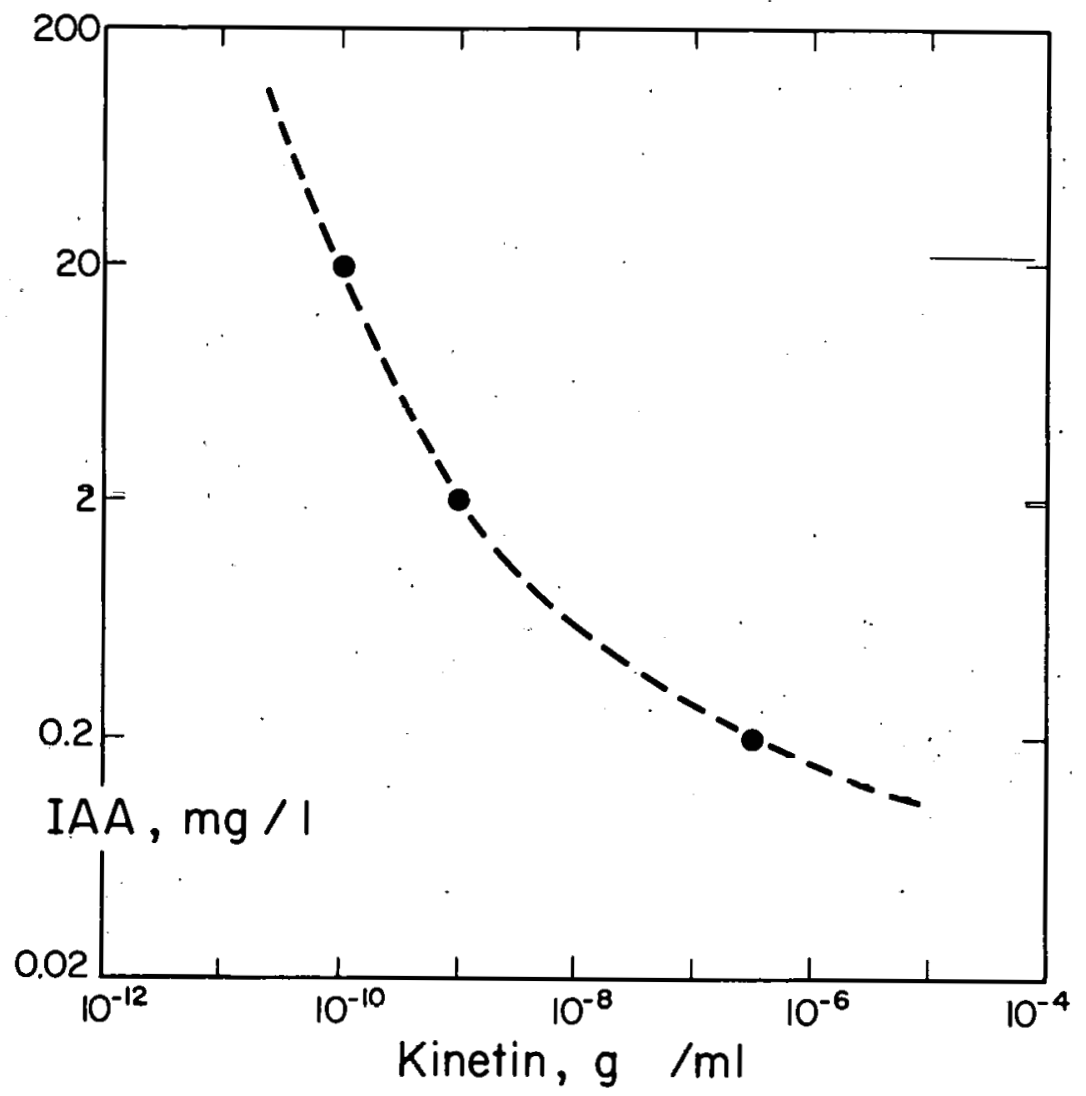

$M U-16386$

Fig. 8. The synergism between IAA and kinetin to produce a maximum inhibition of culture growth rate. For example, at an IAA concentration of $20 \mathrm{mg} / \mathrm{l}$, the concentration of kinetin that produces a maximum effecit is between $10^{-10} \mathrm{~g} / \mathrm{ml}$ and $10^{-11} \mathrm{~g} / \mathrm{ml}$. 


\section{$-33-$}

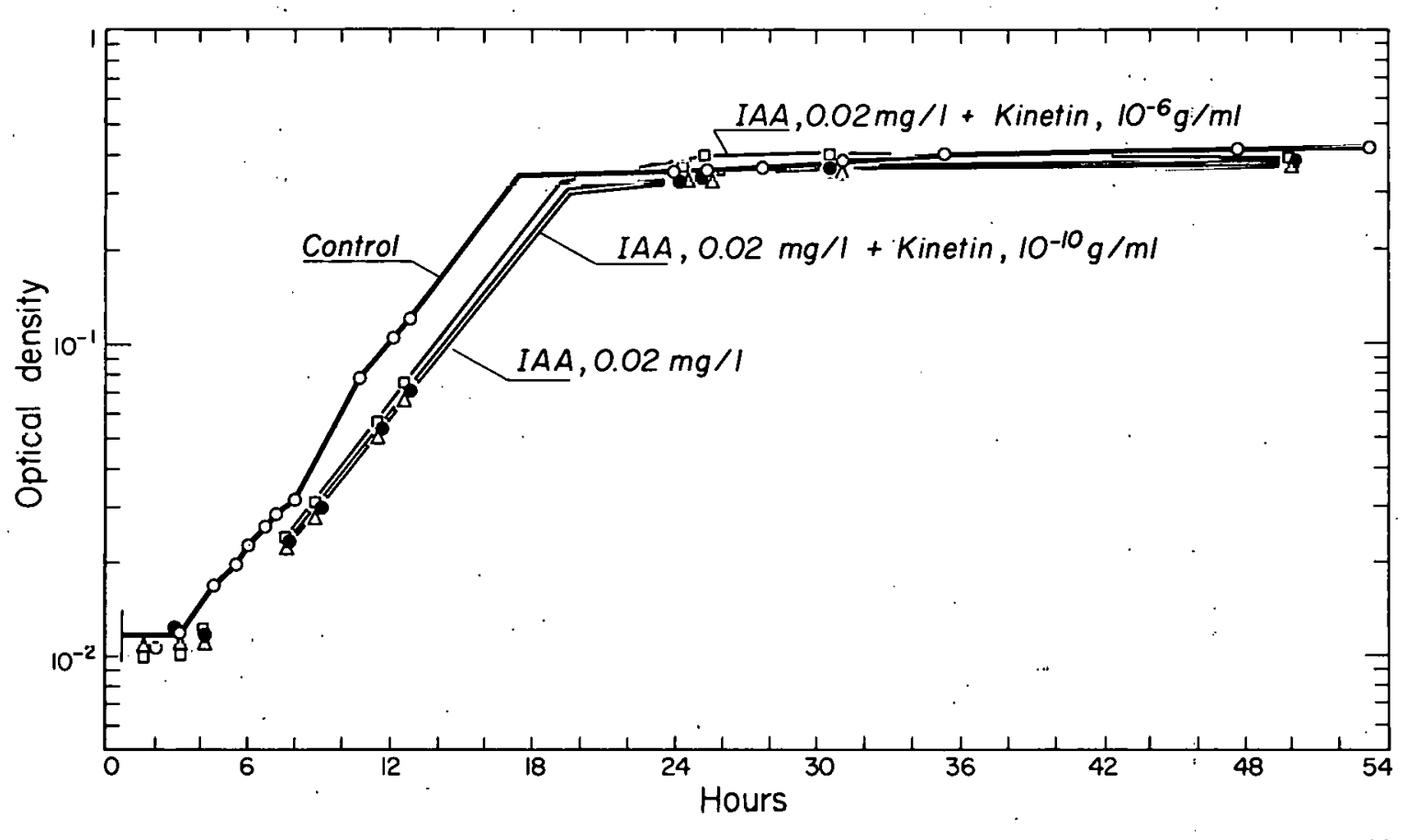

$M U-17086$

Fig. 9. The concentration of IAA must be above a certain minimum level for kinetin, added with it, to produce an additional effect. Growth is measured by optical density. 


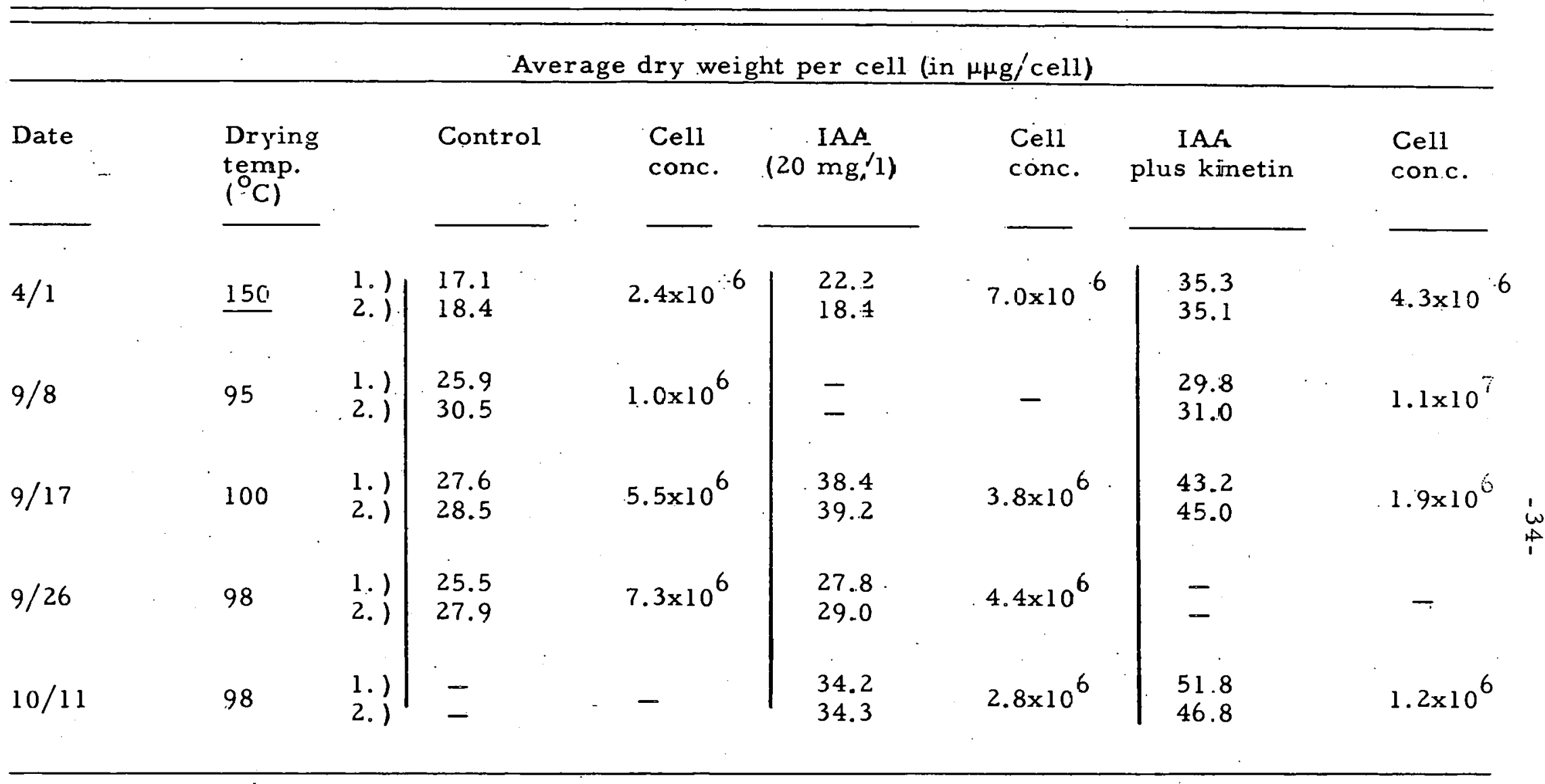


Individual-Cell Growth Studies

Individual-cell studies were done to determine the stage in the cell cycle at which the compounds, were acting. Mitchison recently studied the volume and mass growth of individual S. p. cells. ${ }^{50}$ The change in volume can be followed easily by measuring the change in length, since this cell has a constant diameter. The interphase volume growth is followed :- by a constant-volume or plateau period during cell division.

Control growth is shown in Fig. 10. The interphasic growth is not linear, but shows a gently increase in rate as interphase progresses. The generation time for the individual cells is 2 hours and 40 minutes, which agrees closely with the culture generation time and indicates almost $100 \%$ viability in logarithmic cultures. The constantvolume time is about 39 minutes, leaving 2 hours for interphase cell growth. Mitchison's.values were slightly different because of differences in medium and temperature.

Indoleacetic acid by itself lecreases the interphasic cell growth rate (Fig. 11), while the time required for cell division is unaffected. The generation time for the individual cell agrees with that for the mass culture (four hours) which shows that all the cells are being affected, and further that they are being inhibited equally. Cells which are growing in medium containing IAA plus kinetin have the same growth rate as those with IAA alone but now more time is spent in the constant-volume period. Furthermore, the increased time is primarily, if not all, in the period between the appearance of the cell plate and subsequent fission (Fig. 11). It should be pointed out, however, that this latter conclusion is based upon the time at which the cell plate first becomes 


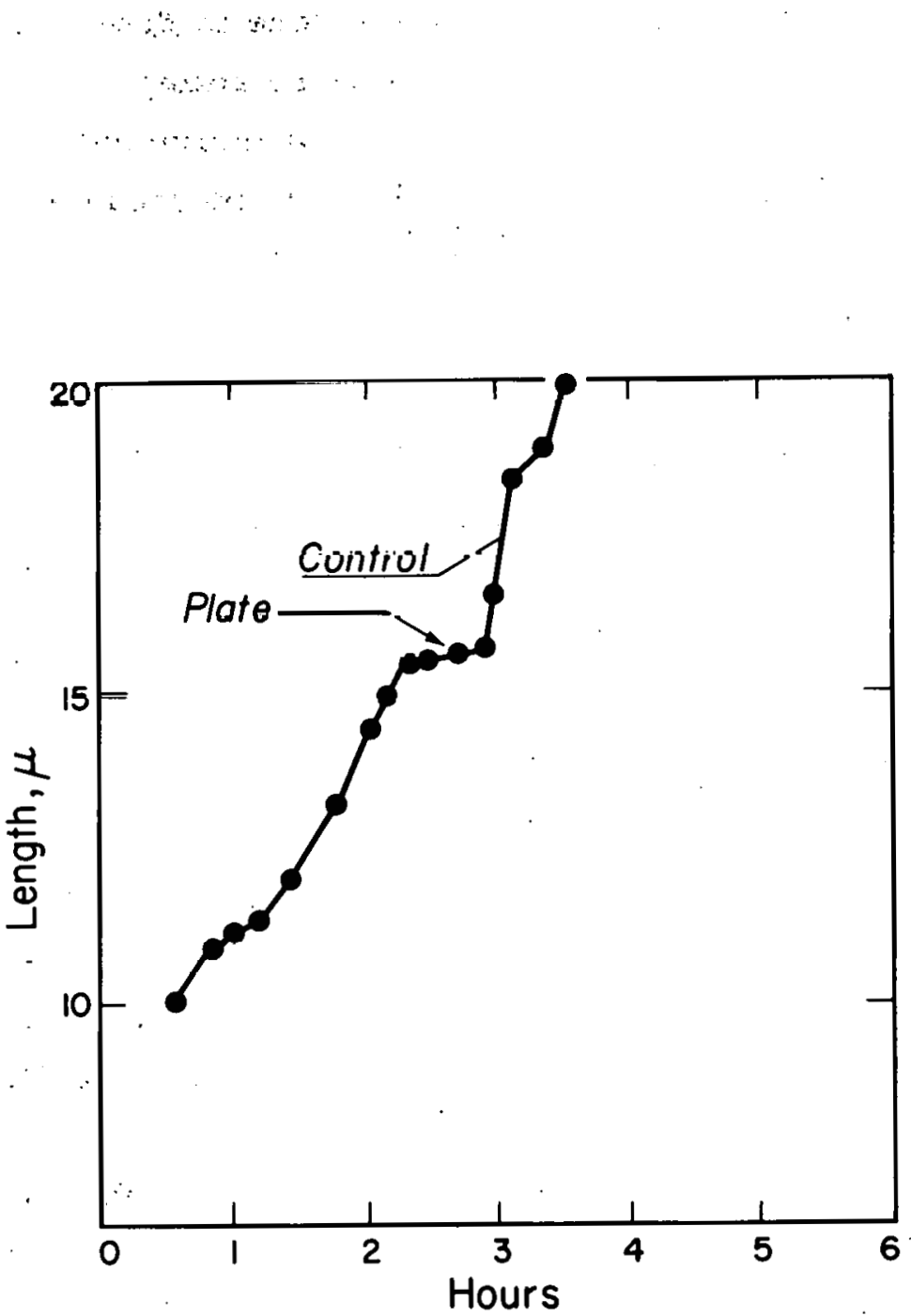

$M U-17085$

Fig. 10. The growth in volume of an individual S. p. cell in synthetic medium. "Plate" refers to the first appearance (under these optical conditions) of the transverse cell plate during the plateau period. Cleavage into two cells marks the end of this period. Volume is measured by cell length (see text). 


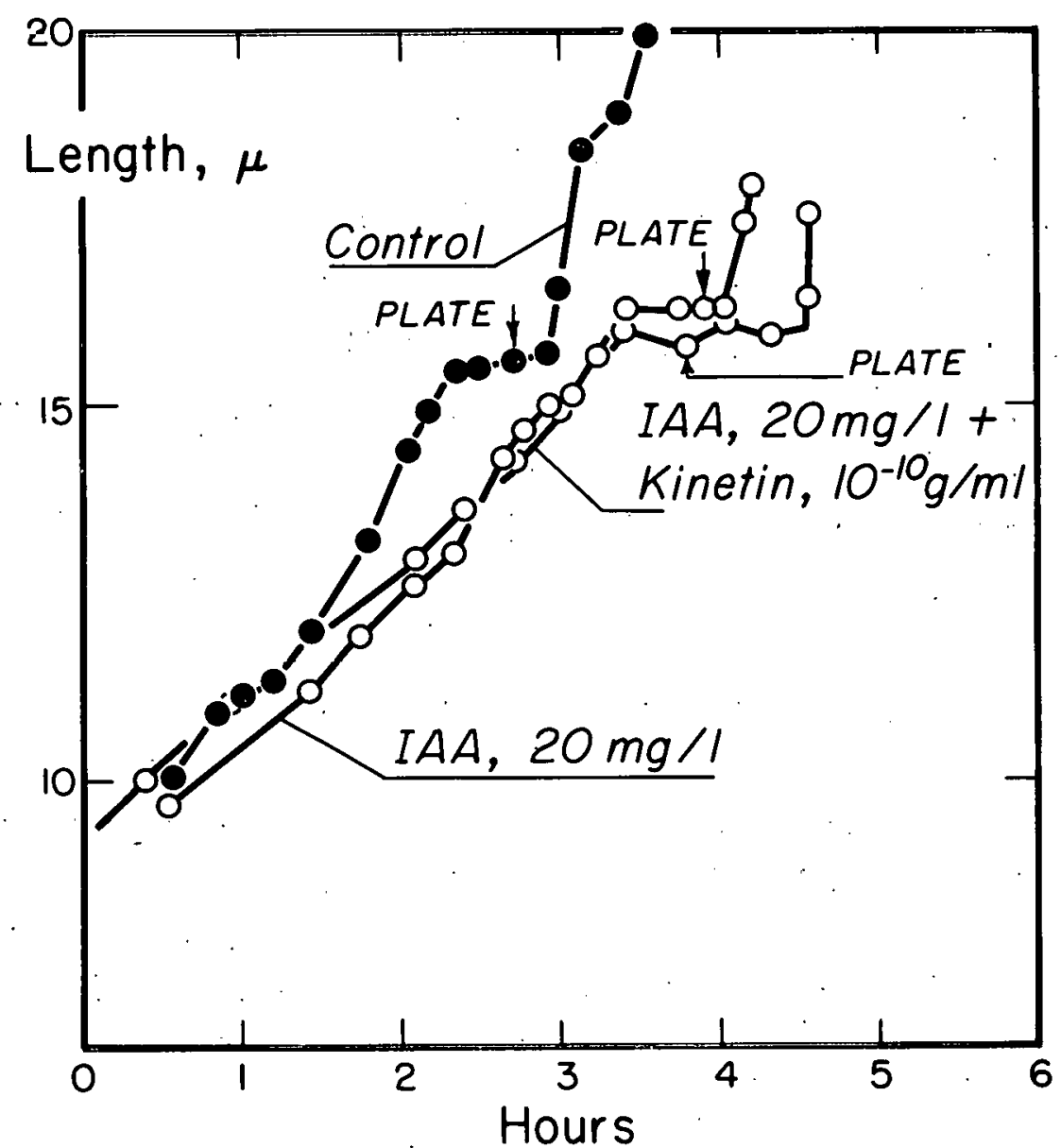

$M U-|639|$

Fig. 11. The growth in volume of individual S. P. cells in synthetic medium, synthetic medium plus IAA $(20 \mathrm{mg} / 1)$, and synthetic medium plus IAA $(20 \mathrm{mg} / \mathrm{l})$ and kinetin $\left(10^{-10} \mathrm{~g} / \mathrm{ml}\right)$. It is not shown here that some of the latter cells remain in the plateau phase indefinitely without dividing. 
visible, which could not be determined with great accuracy under the optical conditions used here. The generation time of the individual cell ( 4 hours 30 minutes) in the presence of IAA plus kinetin does not agree with that of the culture growth. This is because some of the cells (anywhere from 70\% during early log growth to none after several generations) are blocked in the constant-volume stage indefinitely or for a long time. Some of these cells' are very large ard morphologically abnormal. The rest of the cells (the growing population) show a very exact increase in the time spent in the constant-volume stage 163 minutes compared with 39 minutes for controls). The increase in plateau time is exactly the same in cultures of very high kinetin concentratiun as in those of very. low kinetin concentration. As culture growth progresses a lower percentage of cells is completely blocked from dividing; and ultimately the retardation is reversed and culture growth is faster than that of control suspensions.

\section{Alteration of Cells by Kinetin}

In some experiments this reversal of the inhibition seemed to occur earlier in the log phase than in others. Efforts were made to determine the cause of this variability. It was found that stationary cells inoculated into medium with IAA plus kinetin. retain the very slow growth rate longer than do cells from rapidly dividing cultures. Various changes in culture-aeration and cell-aeration history were studied.with conflicting results. However, it is believed that aeration is an important variable in these studies.

The wearing off of the inhibition is not a simple depletion of the chemical, since exactly the same shape of curve is obtained at $10^{-5} \mathrm{~g} / \mathrm{ml}$ as at $10^{-11} \mathrm{~g} / \mathrm{ml}$ (a millionfold difference in concentration).

Also, if cells that have reached the rapid growth phase after growing in IAA-plus-kinetin solutions for several gerierations are washed thoroughly and transferred to new IAA-plus-kinetin solutions, they grow at a greater rate than the controls; thus it is evident that it is not a depletion of the. chemical, but rather an actual physiological adaptation of the cells. 
This same acceleration of growth occurs when cells from cultures with ... IAA plus linetin in: any stage of log or stationary phase are washed and reinoculated into control medium. The generation time for these "activated" cultures is 1 hour and 50 minutes, compared with the 2 hour-50-minute cycle of the control suspensions. This rapid culture growth lasts for three or four generations and then is followed by a rate lower than that of the controls (Fig. 12). The nature of this "relapse" to a slower rate has not been studied, but individual cell studies were made of the fast-growing cells to better understand this intcrcsting reversal of the inhibition.

The formerly inhibited cells had the same growth rate as the controls but now little or no time was spent in the period of constant volume (Fig. 13). The constant-volume time was not uniform in this population of cells, as it had been in the previous individual-cell. studies. For the cell shown.there was no plateau, whereas for others there were plateaus of short duration.

The acceleration of culture growth in.IAA plus kinetin has not been studied on an individual-cell basis. Presumably these cells would show the same pattern as that found for cells which have had the chemicals removed from their environment.

\section{Cytological Considerations}

In order to interpret these results it is necessary to consider the cytology of this cell. As is the case with yeasts in general, there is considerable confusion among cytologists as to the nature of mitosis in S. p. Mitchison observed that the clear vacuole-like structure in the center of the cell divides and re-forms in the two halves by the time of the appearance of the cell plate. This pilates is first visible approximately one-third of the way through the constant-volume stage. With this same yeast Rustad showed, by using a fluorescent nuclear dye, that the nuclear material is in this structure. 51 However, most yeast cytologists would not agree that this "vacuole" is the nucleus itself, although it may be associated with it. 52 


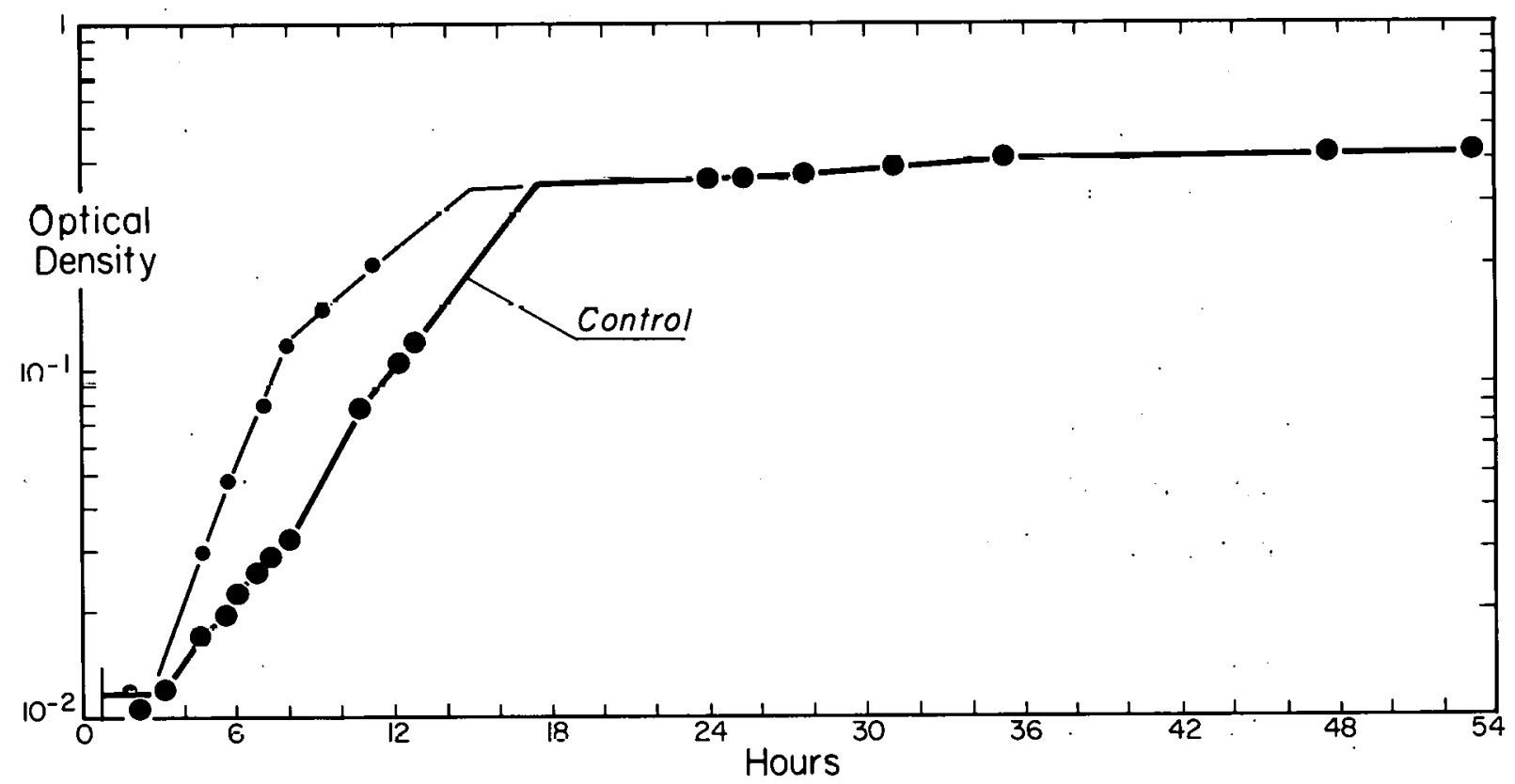

MU- 16393

Fig. 12. Culture growth of S. p. cells in synthetic medium. The control represents cells which had been growing in synthetic mcdium before inoculation; the elevated curve, cells which had been growing in synthetic medium containing IAA $(20 \mathrm{mg} / 1)$ plús kinetin $\left(10^{-10} \mathrm{~g} / \mathrm{ml}\right)$. 


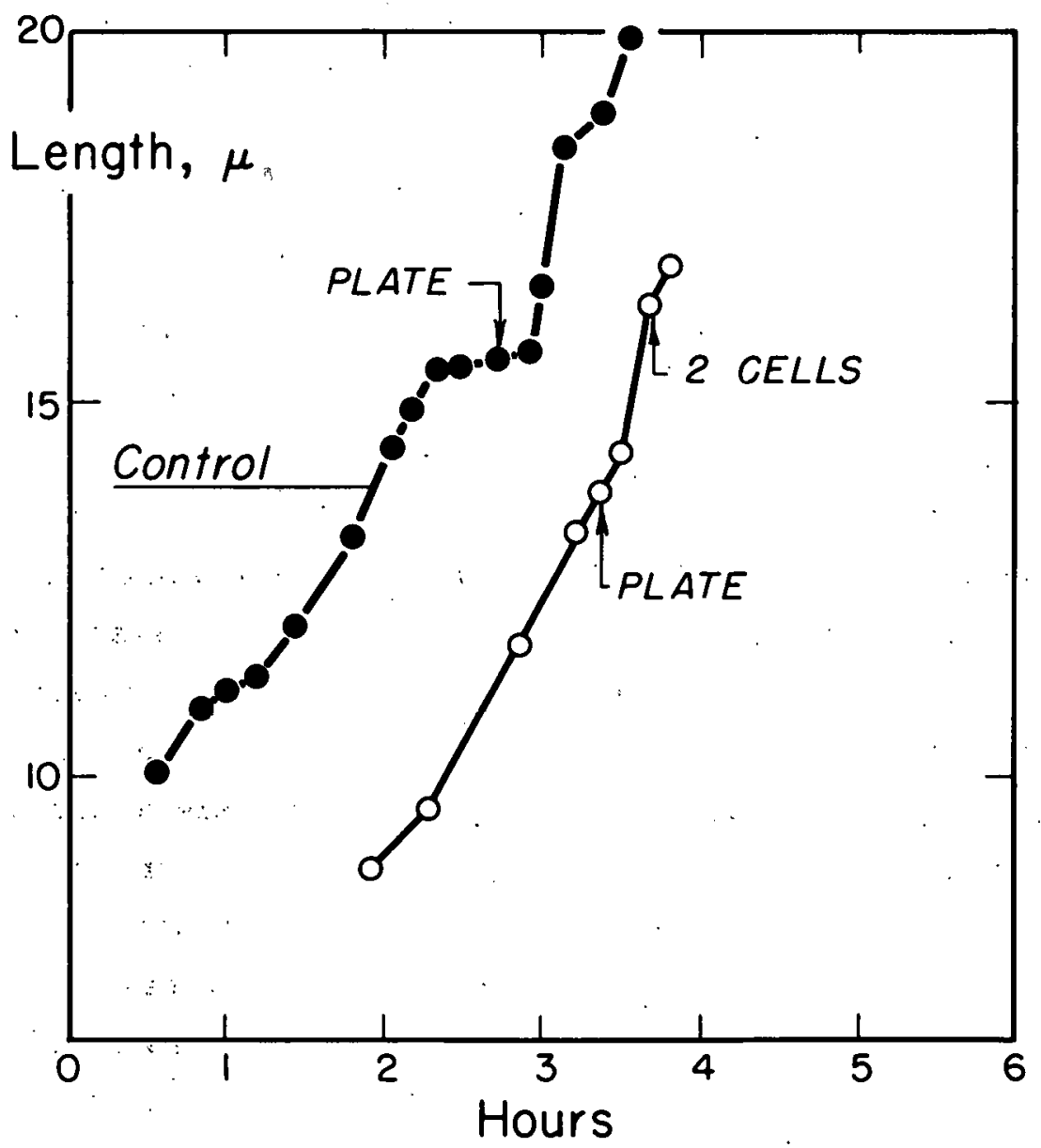

$M U-16392$

Fig. 13. The growth in volume of individual S. p. cells which are growing in synthetic medium after being transferred from synthetic medium to which had been added IAA $(20 \mathrm{mg} / 1)$ plus kinetin $\left(10^{-10} \mathrm{~g} / \mathrm{ml}\right)$. Note that the time from plate to cleavage into two cells is the same as in the control cells. 
It is generally agreed that the nuclear membrane remains intact during division, and some workers believe that chromosomes are segregated by mitosis within the nucleus. $52,53,54,55$

For the purposes of this analysis it is enough to know that by the time of the appearance of the cell plate, mitosis has already reached telophase. This appearance provides a convenient marker to denote the end of anaphase. There follows an even longer time of no cell growth (two-thirds of the plateau time) when, presumably, the daughter cells are reorganizing for interphasic growth.

\section{Interpretation of Results}

Kinetin increases the time required for division and this increase is primarily, if not all, in the period between the appearance of the cell plate and subsequent fission. This is interpreted from the foregoing cytological discussion to be a delay in a postanaphase process. . This does not rule out effects of kinetin on an earlier stage of the cell cycle.

On the other hand, removal of the chemicals from the medium gives cells with little or no constant-volume period, i. e., cell growth is uninterruptea throughout division. Since mitosis of the mother cell. is well advanced very early in the plateau period, growth in this period must represent a premature growth of the daughter cells. That this early growth is not a result of an accelerated cleavage is evillent from the fact that the time required for cytokinesis, as measured from the appearance of the cell plate to subsequent fission, is the same as in the control cell (see Fig. 13). Daughter cells begin to grow before the parent has finished dividing.

The inhibition of the culture growth rate by kinetin during the first several generations is caused entirely by a blockage or delay in the initiation of daughter-cell growth. In inhibition, nowever, therc is also a corresponding delay in the completion of cytokinesis, i.e., cleavage. In other words, the mother cell is delayed in cleaving 
exactly as long as the daughter cells are delayed in starting to grow. This is the situation in normal cells when final cleavage occurs simultaneously with the start of daughter-cell growth. That these events are concurrent indicates that the two processes are related. Either one necessitates the other, or else they both are dependent on a third system. In the fast-growing cells it can be observed that the daughters start growing before cleavage occurs, so that growth certainly can commence without final separation. (Premature growth of this cell before cleavage has been observed in other conditions. 56 Premature cleavage has never been observed.) 'The results'are simply summarized in theistatement that growth does not require cleayage to have occurred": but cleavage: does not begin before growth.

It thus seems reasonable that final separation may depend, indirectly at least, on the inception of functional autonomy of the daughters-specifically, metabolic growth at their own determined rate. If this is true, the final separation of the cells is delayed by kinetin because of a delay in the operation of the systems or systems that determine the growth rate of the individual cell.

Therefore, kinetin produces an observable effect on the time between the end of mitosis and the start of interphase growth. It:may also prolong the time for the final separation of the mother. cell, but I believe that this is probably a result of a delay in the initiation of daughter growth. Certainly the converse is not true, i. e., the start of growth is not mediated via cleavage, since (as was pointed out) growth can commence before cleavage, and therefore is not dependent on it. The discussion of these results considers the possible nature of a growthregulative system as well as evidence for its existence. 
Specificity of Kinetin:.

Finally, it would be of interest biochemically to know the relationship of kinetin to adenine in yeast. In bacteria it was shown that kinetin does not enter the bulk of the adenine-containing compounds either as adenine or as an analog. However, it is possible that kinetin could be used as adenine only when the latter compound is limiting in the cell. This question was investigated by the following experiment with yoat." Eight adonino roquiring mutanto of $\dot{S}_{0} 0_{\text {. }}$ woro platod on agar containing synthetic medium minus adenine but with kinetin at various concentrations. The control consisted of adenine in place of kinetin. All control plates showed some growth even at very low adenine levelo, while kinctin oupported no growth cven at high concentrations.

Therefore, it is concluded that the compound cannot be hydrolyzed to adenine even when the latter is absent or is present only in very small quantities, i.e., they are not in reversible equilibrium.

If we generalize the results for bacteria. and yeast, it appears that kinetin plays a specific chemical role in the cell. This is also indicated by the fact that it is effective at concentrations that are extremely low compared with other physiologically important compounds as well as most drugs. At $10^{-11} \mathrm{~g} / \mathrm{ml}$, the lowest concentration found to have a profound influence, it can be calculated--if one assumes that the chemical is just depleted by the end of exponential growth--that on the order of 10 to 1000 molecules enter each cell at each division.

On the other hand, adenine itself produces a slight inhibitory effect in yeast as well as in some of the other cells used to study kinetin (the original studies. with pith tissue were initiated to find an adenine complex which was more active than adenine). This could implicate an adenine-containing chemical in the cell.

\footnotetext{
"Kindly supplied by Dr. Robert Mortimer, Donner Laboratory.
} 


\section{DISCUSSION}

\section{Indoleacetic Acid}

This work has shown that IAA modifies the interphase growth rate of the yeast cell but not the time spent in cell division. This agrees with the majority of findings on tissues of higher plants, in which the multifold responses are due to a primary action on cell growth. In $:=$ fact, the prieviously quoted definition of an auxin (p.9) makes cell elongation the essential response:

No effort is made here to interpret the mechanism of auxin action in the yeast cell; there are already many theories of auxin action. Although at one time the most popular theories were concerned with biophysical activity such as permeability, cell-wall extension, and osmotic pumps, the most accepted hypotheses, at present, are based on biochemical considerations.

Thimann proposes a deep-seated alteration of the cellular :.. : metabolism, specifically at the level of the four-carbon organic acids. The addition of auxin to the plant medium has been found, in several types of material studied, to cause depletion of four-carbon acids and reducing sugars and an increase of lipids. Also, it appears to be the synthesis of protein that is blocked in cases of inhibition. 56 This theory, then, centers attention on the intermediary metabolism of protein, carbohydrates, and lipids.

Even though there is not always a correlation between growth and oxygen consumption, 57 there are many reasons to believe that auxins do act primarily on certain oxidative systems:although they may not be affecting the total respiration of a cell. For example, anaerobic bacteria are far more resistant to auxin inhibition than are aerobic bacteria. 58 "Likewise, rice seed, which has an anaerobic metabolism, is resistant, while barley seed, which has an aerobic metabolism, is sensitive to 2, 4-D inhibition. 59

Recently, a very fine study has shown that there is an immediate increase in high-energy phosphate, which is accountable as ATP; upon 
the addition of IAA to pea seedlings. This increase is followed by a decline of the compound as equilibrium with the metabolic needs of growth is reached. These observations point to activation of growth via a primary action on oxidative mechanisms rather than the reverse. 60 This interpretation, however, is still a major point of contention. $h 1$

As has been mentioned earlier, IAA has been shown to increase the fermentation rate of Saccharomyces cerevisiae 24 as well as to increase the uptake of oxygen in low-glucose medium. 25 Also, the glycolysis and respiration of liver tissue can be modified by exogenous auxin. 30 of course, these may not be primary effects.

The influence of anaerobic versus aerobic conditions on the response of yeast to IAA has not been studied with conclusive results. It would seem reasonable for the effect on the growth rate to be a function of the presence or absence of oxygen if IAA influenced fermentative mechanisms of this cell.

So far as the nature of the physiological response is concerned, IAA does not appear to effect a perrnanent.change in the yeast cell. Cells that have been growing in a medium containing both compounds resume the normal control interphase growth immediately upon removal of IAA and kinetin. Since IAA changes only the interphase growth rate, it shows that there is no carry-over of the chemical's influence after its removal. This agrees with the findings of Mitchell et al: that the inhibition by auxin of oxygen uptake in root and stem. slices of several plant species is readily reversed by simply washing the tissue. 62 Also, the early experiment of Audus showed that root-growth inhibition by $2,4-D$ is also reversible.

These results in conjunction with our knowledge of auxins point to an action of IAA on certain basic metabolic processes of the cell, possibly oxidative systems. The action of.IAA results in an increased or decreased growth rate. Finally, it acts by modifying some system 
which is in dynamic equilibrium with the environment so that the removal of the auxin results in an immediate return to the normal growth rate.

\section{Kinetin}

In yeast, kinetin has been observed to produce a visible effect only at a specific stage of the cell cycle, i. e., between anaphase of the parent and interphase growth of the daughters. This stage is longer for cells in slow-growing cultures and is absent from or shorter for cells of the fast-growing cultures than it is in cells of control cultures. Thus, while IAA exerts a continuous effect during, and only during, the entire interphase growth of the cell, kinetin does not alter the rate of growth but only the time between the formation of the two new nuclei. and the commencement of interphase growth. It is not known whether bacteria and amoebae are affected at the same stages of their cell cycles as yeast.

Probably the most important assignment in this period of telophase (or its equivalent in yeast) is the preparation by the mother cell of apparatus that will insure the interphase growth of her daughters. At least we know, from studies of the growth of individual cells or synchronous populations, (see p. 49), that usually there is an abrupt change from a $1 \mathrm{x}$ rate for a mother cell to a $2 \mathrm{x}$ rate for the sum of its daughters. Considered in terms of protoplasm and not simply cells; this means'that the system or "machinery" that regulates the rate of protoplasmic synthesis is duplicated or activated to a $2 \mathrm{x}$ value during cell division. Kinetin alters either the rate of this duplication or the

- moment when the machinery first begins to function.

While this is the observed result of its presence, kinetin may produce this effect via a primary action on any of the various general processes of the cell such as the rate of cell wall synthesis, permeability, or even internal $\mathrm{pH}-$-but if this was so it would mean that these 
factors suddenly became important to the cell at this time but had no effect on the previous over-all cell-growth.rate. Although this may be true,: it would be senseless to try to discuss the infinite number of physical and.chemical events which could be the ultimate trigger (if such exists) for the initiation of gruwll. Ratler, wc havo a considerahie body of evidence that ribonucleic acid, as a specific component of the cell, is directly involved in determining not only the type of proteins that are polymerized in the living cell but also the rate of their synthesis. In addition, there is evidence (although fragmentary) from other work that kinetin may be altering the metabolism of this nucleic acid.

First, let us review some of the experiuctital data that aro used to justify a growth-regulating role for R NA before wc cramine the available evidence for the hypothesis that kinetin affects the initiation of growth via $R$ NA.

$\underline{\text { Ribonucleic Acid and Protein Synthesis }}$

Direct biochemical studies on cell extracts have shown the ability of imixtures of a low-molecular-weight RNA plus cellular enzymes at the correct $\mathrm{pH}$ to form activated amino acid complexes. It is further postulated that this amino acid is transferred from this - RNA to a high molecular-weight RNA of the microsomes to participate in peptide linkages. 64

Blocking RNA metabolism causes an interference with the synthesis of induced enzymes in bacteria and yeast. 65, 66. Various studies have been made on the relation of RNA to general protein synthesis in bacteria 67 and in mammalian tissues. 68

Very elegant work has been done.during the last several years by Gale and Folkes on disrupted-cell suspensions of staphylococci. Here the ability of the susperisions to incorporate amino acids into protein is lost when they are treated with DNase or R Nase. However, protein synthesis, as measured by induced or constitutive enzyme formation, can be restored by adding to the suspension DNA, RNA, or a mixture of nucleotides, depending on the particular protein. 69,70 
Physical chemical studies are under way to determine the nature of the chemical bond between RNA and specific amino acids. 71 Although the hypothesis that there is a direct relation between RNA and protein synthesis is well founded, the conclusion that RNA regulates the type and amount of it is still in the testing stage. Early fork showed that the rate of protein synthesis, and thus of growth, is proportional to the average total amount of RNA per cell. $72,73,74$ Fast-growing cells contain more RNA than slow-growing ones. However; there are undoubtedly many components of the cell--such as high-energy compounds, enzymes, and. "machinery substances" in general--which increase in concentration to allow maximal growth. The first step. in showing. a causal relationship is to demonstrate a proportionality between rate of protein synthesis and amount of RNA or its rate of synthesis, not in the average cell, but in the individual cell. It has been more difficult to find a direct relation between these components from a study of them in the individual cell or in synchronous populations of cells. It is necessary to review our knowledge of the cell cycle.

Mitchison, measuring the dry weights of individual S. p. cells in his original work, found that the mass increased linearly until division, when it abruptly doubled its rate of increase to correspond to two cells instead of one. The individual-cell volume growth was not quite linear, and showed the characteristic plateau during division. He interpreted this finding of a discontinuous mass curve as indicative of the duplication of some component of the cell which determines the rate of mass synthesis. He postulated the microsomes, but other organelles are 
worthy of consideration. *

From work on other cells, also, there is evidence, although there are possible exceptions, that growth is not normally autocatalytic. That is to say that the machinery for cellular syntheses produces new protoplasm at a uniform $x$ ate throughout interphase and then is duplicated at division to supply the needs of two cells instead of one.

Most other studies of individual cell growth also show. nonautocatalytic growth between divisions, indicating the duplication, at division, of growth-controlling machinery which controls the rate of growth until the next division. For example:

1. Prescott found the mass and volume to increase at a slowly decreasing rate for individual Amoeba proteus cells. 76

2. Tlie same author otudiod protein synthesis in individual Tetrahymena cells, using autoradiography, and found a straight-line increase during interphase.

3. Zeuthen found respiration of synchronous cultures of Tett rahymena to be linear during growth and to level off just before division. 78 However; Scherbaum and Zeuthen reported volume increase and protein growth were exponential between divisions. 79 These same authors questioned their method of measuring protein synthesis (dye uptake). The more recent work of Prescott is probably more accurate.

4. Maruyama studied syntheses in synchronous cultures of E. coli bacteria: ${ }^{80}$ The curves for protein and total

* Professor Mazia pointed out in a discussion that the growth, as measured by volume in yeast, as well as mass and volume of Amoeba, seems to follow a rate of 1,0,2 for the periods of interphase, division, and two daughters. If we assume that the rate is governed by a functioning organelle, the most obvious if not the only apparent unit is the nucleolus, of which there are $1,0,2$ for the same periods. The nucleolus is the site of the most metabolically active RNA. 7.5 
nitrogen were interpreted as being nonlinear, although more points were needed for a conclusive determination. Recently, Abbo, using synchronous populations of the same cell, found a linear increase in protein during interphase. ${ }^{81}$.

It is important to recognize that the cell growth rate may show marked differences when growth is measured according to different variables, such as respiratory rate, uptake of a metabolite, dry weight, volume, etc. For the purposes of a study of the regulation of macromolecule..synthesis in the life of a cell, protein synthesis itself is probably the miust isupurlant variable, and may not be proportional to uptake of a metabolite or any of the other variables mentioned. I believe that, for the fission yeast used, volume growth is actually a. more accurate measure of macromolecule synthesis than is the dry weight.

Therefore if the growth-regulating machinery douples at division, and if ribonucleoprotein is a major part of it, one might expect to find a major synthesis of RNA during the late stages of division. This question has been investigated in the following works.

1. Maruyama found that. RNA is synthesized during and immediately following cell division of synchronized E. coli bacteria. Furthermore, protein synthesis commences just after RNA synthesis has leveled off. 80

2. The R.NA content of Amoeba proteus cells was not found to change during the division process. 82

3. Iwamura found that $\mathrm{R} N \mathrm{NA}$ increases at a rate proportional to the growth in Chlorella cells, ${ }^{83}$ while Prescott observed a sharp increase in RNA content per cell during the last third of interphase, or prior to division, in Tetrahymena pyriformis. 77

4. :With the. S. p. yeast cells Mitchison has found a steady increase of RNA during growth and division. 84

Therefore, from these and other works, there is not much experimental evidence of doubling of RNA at or just following division. 
Due to the early work of Caspersson on mass cultures mentioned earlier, many workers have assumed that the rate of growth is proportional to the absolute amount of RNA or of a component of which is is a part. It can be seen that for the individual cell this is not true. However, it is possible (and in fact probable) that $\mathrm{RNA}$ is bound or inactive in the cell until activated by some factor.

One hypothesis to explain the doubling of the growth rate at the time of division is the passage of material from nucleus to cytoplasm at division itself. An interesting finding in Amoeba proteus is that nuclear $R N \dot{A}$ material appears to be dumped into the cytoplasm during division, leaving the nucleus "bare" as seen by autoradiographic and staining techniques. At this time a considerable proportion of the RNA of the cell is transferred trom nucleus to cytoplasm. 85

Mazia and Prescott suggested that nuclear protein synthesis may merely'reflect production of ribonucleoprotein, which then passes to cytoplasmic centers to be functional in the synthesis of other proteins. 86 If growth is not autocatalytic, the nucleus would be expected to deposit this in a noncontinuous fashion. However, the actual synthesis of cellular nucleoprotein may be occurring at a uniform rate or at a time and a rate that could not be correlated with the degree of protein synthesis.

Another class of hypotheses supposes that the amount of RNA in the cytoplaom io not limiting but that its activity is a function of some contrio bution from the nucleus. Nuclear division could conceivably involve the doubling of the activating mechanism and therefore be responsible for a switch from a $1 x$ to a $2 x$ rate of growth.

This would mean that, at any time during the cell cycle, most of a cell's RNA is not functioning, i.e., it is waiting to be transported and (or) activated to centers of protein synthesis. In this connection, it has been proposed that bacterial RNA may become inert after its initial use in protein synthesis, ${ }^{65}$ and synthesis of nonfunctional RNA has been proposed for a particular mutant. 87

Therefore, if ribonucleoprotein is responsible for protein synthesis, its activation or release by a factor during division may be as important as its synthesis, so far as correlating an event with a simultaneous increase in the rate of protein synthesis is concerned. The formation of the two nucleoli during telophase could be this event. 
Kinetin and Ribonucleic Acid

To complete this line of reasoning there is evidence that kinetin affects. RNA metabolism.

Guttman, using meristematic tissue of onion root, found that kinetin increased mitoses as well as modified the relative duration of its stages. From statistical analyses she inferred that prophase was shortened and telophase lengthened. ${ }^{88}$ She proposed an effect on chromosomal coiling via chromosomal RNA. The latter conclusion came from the fact that treated cells showed large amounts of nuclear RNA associated specifically with the chromosomes. ${ }^{8}$. Although she. had no evidence for a coiling role, the proposal of an effect on.chromosomal RNA during telophase is in agreement with the ideas presented about the results with yeast.

Pea root meristematic tissue cells are inhibited from dividing by kinetin and show abnormally high concentrations of RNA. ${ }^{4}$ This concentration could be due to an inability of the RNA to be distributed from the nucleus to the cytoplasm, simply to a piling up of the nucleic acid, or to a higher rate of synthesis.

Recently, autoradiographic studies of onion root cells have shown that kinetin causes an altered uptake of $\mathrm{C}^{14}$-adenine. 90 Grain counts were made over the cytoplasm, nucleolus, and nucleus. It was found that the compound, when added with $\mathrm{C}^{14}$-adenine, causes an increased synthesis or turnover of $\mathrm{R} N \mathrm{NA}$ in the nucleolus during the first 5 hours and a decreased activity in the nucleus and cytoplasm. Similar results, except for a time difference, could be obtained by pretreatment of the tissues with kinetin. It would be difficult to interpret these results in terms of an indirect action on RNA metabolism, and they give significance to the previous findings of increased amounts of cellular.. RNA in onion and pea tissue. 
$\underline{\text { Kinetin in. Biological Material }}$

It is important to know if kinetin or its product is a normal constituent of the cell or is acting as an abnormal añlog to a normal constituent.

There are a great many similar compounds (6-substituted purines) which have been investigated as possible antitumor agents, especially 6-mercaptopurine? 91,92 A direct competitive relationship with the natural purines appears to exist here. However, in this work it has been shown that kinetin is certainly not competing with adenine in yeast or bacteria in any direct way.

It would be very difficult to prove the presence of very low concentrations of kinetin in cells. There is indirect evidene for its presence in yeast and vascular tissue of tobacco. First, it has been shown to be present in yeast extract. There it either is present in yeast as such or is an artifact produced in conversion to an extract. 7 In the original works of Skoog, it was found that of many compounds tested onlye kinetin replaces surre factor which diffuses from vascular tissue to act on inert pith cells in the presence of.IAA. 33,46 Therefore the evidence points to the presence of kinetin in biological material, but it is not conclusive.

Wliellier or not kinetin io a normal constituent of cells, there is an adaptation of the cells to the levels present in the medium, i.e., kinetin produces a permanent or semipermanent change in the cells. On semilog plot the growth is not a straight line, but after several generations approximates or exceeds the control slope. As pointed out previously, this is not a simple depletion of the chemical but, rather, points to an adaptation of the yeast cells to the new conditions. Also, when the cells are transferred from medium in which the inhibiting chemicals are present to control medium, there is an immediate increase in growth rate for three or four generations. Clearly these cells are physiologically different from untreated ones (controls). 
Therefore, whereas the effect of IAA on the over-all metabolism is nonpermanent and immediately reversible, kinetin appears to alter the cell.

\section{Kinetin and Cell Division}

Should kinetin be regarded as a cell-division trigger?

There is abundant evidence that the processes of cell division should be considered as partially independent of cell growth, or at least concerned with different systems in the cell. 93 Mazia defines a trigger mechanism as "... simply the achievement of some condition which precipitates division irrevocably. ${ }^{94}$ In its first known role as a factor that causes dormant pith cells to divide rapidly kinetin seemed to meet the expectations of a trigger:admirably. The fact that in other circumstances it blocks or slows the same processes should not detract from its importance as a cell-division factor.

In fact, kinetin appears to act as a moderator of cell-division rate. The chemical stimulates cells which have stopped dividing to divide again (e. g., tobacco pith and pea root callus tissue), and inhibits or slows cell division in rapidly dividing cells (e. g. , meristematic tissue. and yeast). This is not unusual. Promotion and inhibition are two sides of the same activator in most cases. Suppose we use as an example the RNA-chromosome association during division as the process which is sensitive. If kinetin facilitates the union of ribonucleoprotein to the genetic material--DNA or chromosomes--then it would facilitate mitosis in those cells in which this was the limiting factor for division while in those cells in which the association is normal, it would prevent the dissociation of the two components in telophase and appear to block division.

This is an oversimplified model, and according to the recent studies by Olszewska, the metabolism of RNA is probably more pertinent to the action of kinetin, but an analogous example could explain acceleration in some cells; and inhibition:in others. $\therefore$ 
In yeast, although kinetin may also act before mitosis or in its early stages, the effect on the cell's growth pattern becomes evident only at a later time, so that in these investigations it appeared to act after anaphase.

Thercforo, it is prohahle that. in yeast, kinetin is not a trigger substance of cell division in the usual sense of the word, i.e., initiating mitosis. But it is a factor important to the initiation, during division, of the new growth-controlling apparatus of the daughter cells. This in turn is seen as an apparent effect on cell division, since the final tission is delayed proportionately. Whether this is generally true in other cells such as the tobacco pith tissue is not known, but it is not contradictory to the ubservationo reported.

Further, from the intensive studies by many invcctigators, there. is reason to believe that ribonucleoprotein is responsible for the regulation of the rate of cprotein synthesis in cells, and it is proposed that kinetin may produce the observed effect by altering RNA metabolism at a stage of mitosis when the daughter cells are preparing their machinery for interphase growth. 
EVIDENCE FOR INTERNAL REGULATION OF CELL GROWTH

Purpose of the Study

It has been obserfied that after a cell has completed mitosis, kinetin delays (or hastens) the moment when daughter cell growth will commence. Evidence was presented (p. 49 ), from studies of normally growing cells, for the existence of regulative machinery which appears to duplicate at division to elicit $2 x$ growth. Hence kinetin is delaying either the synthesis of this machinery or the moment when it first functions. It would be desirable to have further evidence, especially for this cell, that growth (in volume) is regulated and, furthermore, that the system that regulates it is duplicated during division when kinetin is observed to act. Although other studies have indicated.this regulation in normally growing cells, these simple experiments done with cells growing in a suboptimal medium show very clearly. the existence of this regulation in the yeast cell.

\section{Cell Growth.in Starvation Medium}

Preliminary studies of the same nature were done by Mitchison and Mazia, and after I had made the observations reported here, my attention was called to very similar, but more extensive, experiments which. were performed in much greater detail. by Faed, working in Mitchison's laboratory. 95 . Faed made his observations on cells growing on agar media; all my experiments were on cells growing in liquid on a clinical haemacytometer (see p. 26).

When cells are grown under. suboptimal conditions, it is often possible to separate various processes of their physiology that are independent to some extent. If cells that have been growing in a complete medium for several generations are washed thoroughly and resuspended in a medium with only a carbon source, but no nitrogen, the type of growth obtained is as shown in Fig. 14. The yeasts were washed by centrifugation five times to achieve a total concentration of the original medium of 


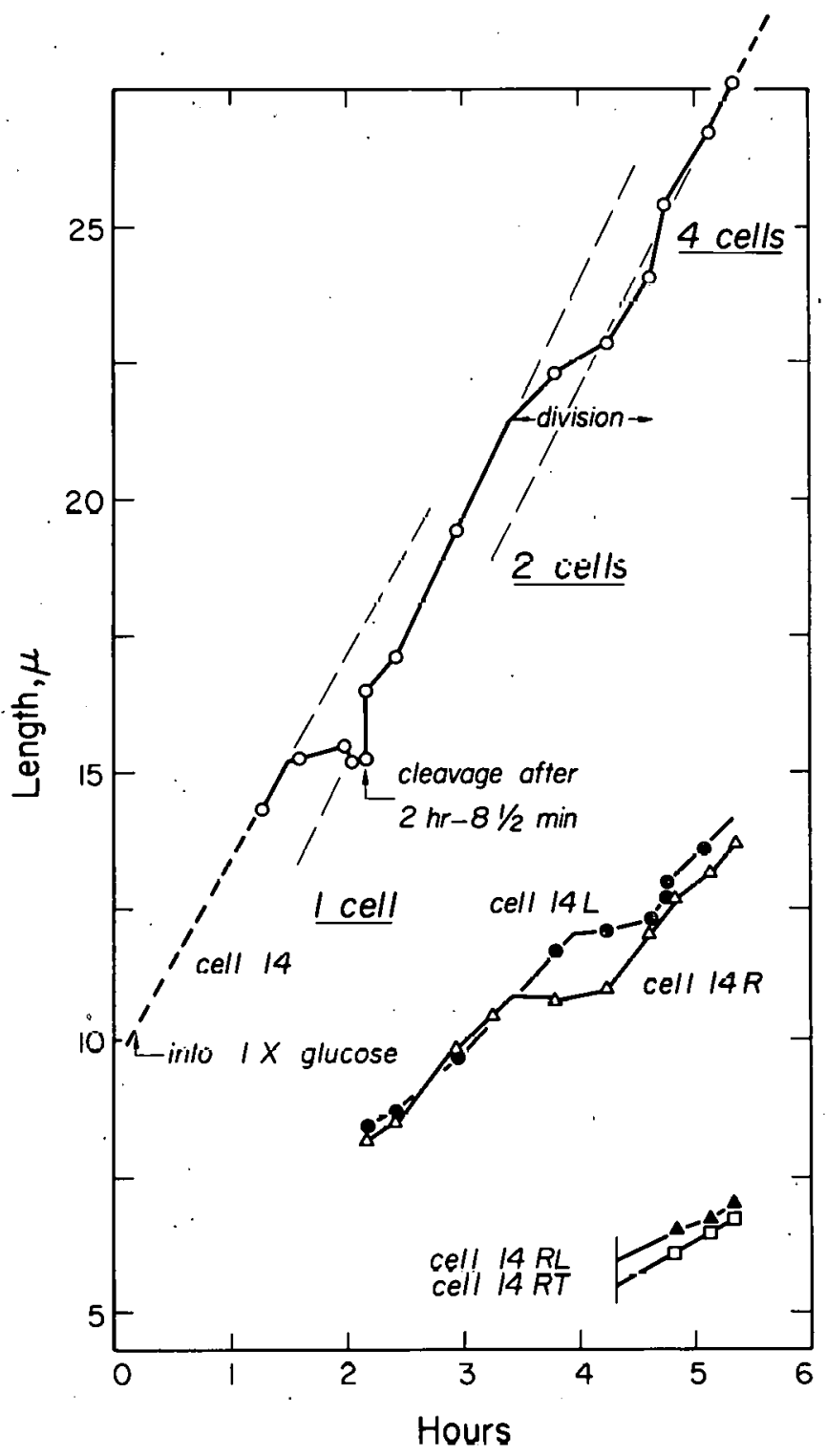

$M U-17088$

Fig. 14. The growth in volume of individual S. p. cells in $0.5 \%$ glucose. Cells growing exponentially in synthetic medium were transferred into the glucose medium at the time indicated. Cells $14 \mathrm{R}$ and $14 \mathrm{~L}$ are the daughters of cell 14, and cells $14 R \mathrm{~L}$ and $14 \mathrm{RT}$ are the daughters of cell $14 \mathrm{R}$. The top curve gives the total growth of the original cell. 
no more than one part to a million. The results can be summarized best by a brief listing:

(a) Cells can grow and divide for a limited time in the presence of only a carbon source. Faed speaks of a period of division after growth when the cells divide without any interphase growth. In the experiments reported here there were no cases of division without interphase growth before and after it.

(b) However, cell size does decrease, because cells do not grow to full size before dividing.

(c) The generation time is shortened.

(d) The most interesting finding is that the growth rate for any mother cell is the same as the sum of that of its daughters, so that for the individual cell the rates are $1, \frac{1}{2}, \frac{1}{4}$ for mother, daughter, and granddaughter. This is shown best for cell No. 7 in Fig. 15, where the daughters happened to divide synchronously. Also, see Fig. 14.

It should be mentioned that the nitrogen pools. of yeast account for only $5 \%$ to $12 \%$ of the total nitrogen of the cell and the pools, as such, could supply only a small fraction (about 10\%) of the needs of one generation.

Several interesting conclusions may be drawn from these results. First, even though the cells are under nitrogen starvation, they divide more often (between 1 and 2 hours instead of a 2-hour-40-minute generation time). The only explanation for this unusual behavior is that division processes are being favored at the expense of some other process which competes with reproduction. This result could support Swann's hypothesis of an energy resevoir for division which must be filled before this process can be initiated. If the cell diverts energy to growth and division processes independently, then the restriction of growth by: a lack of nitrogen. could fill up the division resevoir faster. On the other hand, the accelerated multiplication could be due to a more subtle alteration of the cell's metabolism. This is not discussed further since it is somewhat removed from the original purpose of this section. 


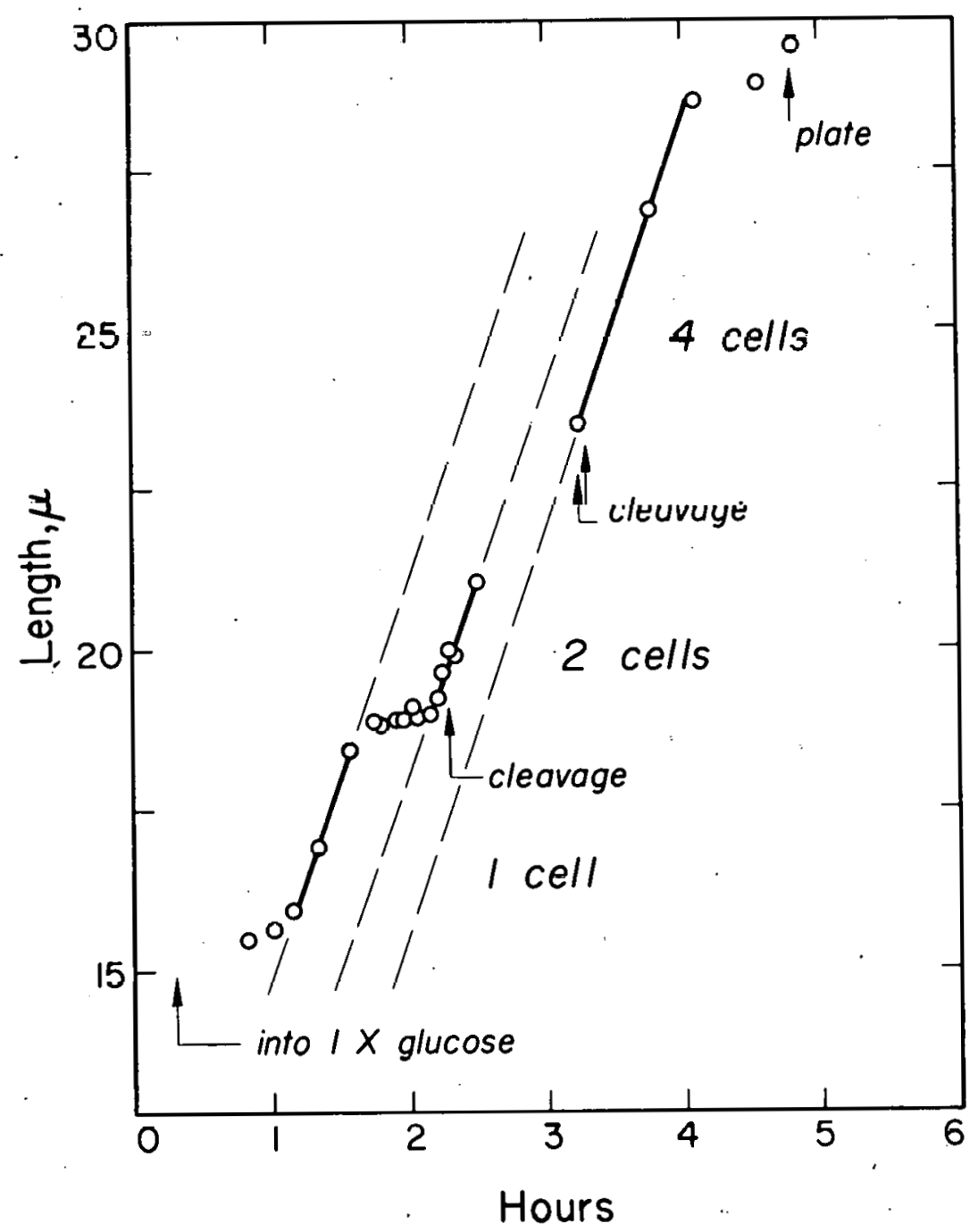

MU -17084

Fig. 15. The total growth in volume of an individual S. p. cell in $0.5 \%$ glucose (see Fig. 14). 
Furthermore, the growth rate is decreased in a very ordered way, i.e. . by geometric progression as division occurs. There are two possibilities. Either the reduction. in growth rate is due to a dilution of the growth-regulating machinery, or the machinery is still synthesized but cannot be utilized because of the (lack of) nitrogen. This was investigated ...by the following simple experiment.

-When a nitrogen source is added to cells that have been growing for approximately three generations ( 5 hours) on glucose alone, the normal growth begins immediately or after only a short lag, as shown in Fig. 16. (As the synthelic medium was pale yellow, it was easily seen, by the change in color of the solution, to diffuse over the haemacytometer within a few seconds after it was added.) In fifteen cells studied the lags varied between zero and 60 minutes, with an average of 20 minutes. There was some tendency for smaller cells to show a longer lag. All then resumed the normal growth rate. This lag is undoubtedly simply an adaptation to a "new" medium. The cells had been growing in $0.5 \%$ glucose on the haemacytometer for 5 hours when $10 \mathrm{x}$ synthetic medium was added. Faed observed longer lags followed by more gradual increases in growth rate. This difference may be due to the use of agar (rather than liquid medium) in his work. The slower rates of diffusion in Faed's work could account for the long lags between the change in medium and an observed effect.

That normal growth is resumed very soon means either that the growth-regulating machinery is always present in full amount or that it can be synthesized.at any time in the cell cycle and is synthesized in preference to general protein synthesis following a period of nitrogen starvation.

Therefore, the rate of cell growth in glucose follows a very definite pattern of $1, \frac{1}{2}, \frac{1}{4}$, and returns to a $1 \times$ rate when returned to complete medium. "The significant aspect of this growth is that the rate is ordered and, moreover, that it changes only at division. Even after a cell has depleted its reserves of nitrogen, it continues to grow at a normal rate until it divides and only then is the lack of nutrients apparent 


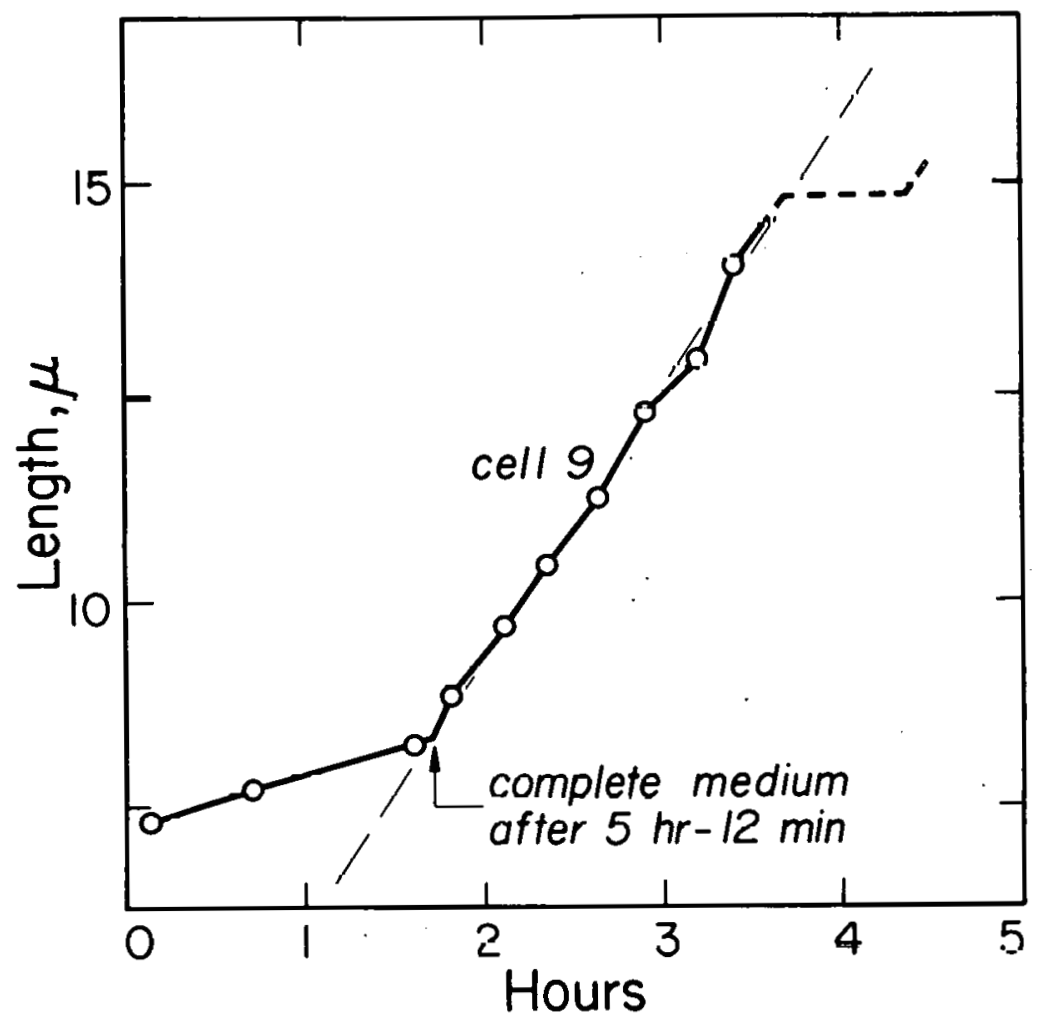

$M U-17083$

Fig. 16. The growth in volume of an individual S. p. cell which has been growing in $0.5 \%$ glucose for 5 hours 12 minutes when it is provided with complete synthetic medium. 
in the growth of its daughters. They continue at the $\frac{1}{2} \mathrm{x}$ rate until the next division. The fact that the rate of cell growth does not gradually decline under these conditions of starvation is direct evidence of a quite rigid growth control. Further, the fact that the points of discontinuity, when the rate is reduced in half, occur at division, indicates that at this time the cell would normally produce regulatory machinery which would quarantee a continued $l x$ rate for each of the daughter cells. The lack of nitrogen at this time prevents the cell from duplicating the system and thus the $1 x$ rate is maintained for the sum of the daughters rather than for each. While the normal pattern of growth in complete medium leads to the same conclusion, these results show that the regulatory machinery of the cell determines the synthetic rate even under the limiting conditions of this environment.

The only time when a sharp discontinuity is observed in the rate of interphase growth is when the third-generation cells are transferred to complete medium and normal growth is resumed. It is legitimate to ask how the cell knows its normal rate of growth and returns to it instantly when put into complete media. There must be some template or organizer, present even in the starved cell, which tells it how fast it can grow when returned to an adequate medium. Therefore, the "ultimate" regulator is still present, i.e., it must have been duplicated at division even during starvation.

Therefore, it is the secondary templates or factors that have been diluted geometrically at division, whereas the primary ones--which apparently control them--are present at full strength. . These ideas can be brought into better focus by assigning names to the components. The ultimate templates could be the genetic units of DNA (which have certainly duplicated at division), and the secondary templates R NA (or a fraction of it which directly controls the rate of synthesis of all macromolecules except the nucleic acids.) The evidence for a regulatory role for RNA has been discussed previously ( p.48ff). Whether the nucleic acids of the cell perform this role or not is still at the level of a good hypothesis. 
In conclusion, the evidence, is quite good that protoplasmic syntheses are rate-dependent on specific cellular units. In these studies it could be shown that when these specific units could not be duplicated because of want of nitrogen, their deficiency became apparent only after the completion of cell diviston and the slatl uf interiphage growth. Therefore it was concluded that they duplicate lduring division. These findings lend further support to the contention that the observed effect of kinetin on the time between the formation of the two daughter nuclei and the start of interphase growth is an effect on a specific growthregulating component of the cell. (This component may be ribonucleoprotein.) 


\section{ACKNOWLEDGMENTS}

The author is grateful for the continuing interest and gracious aid of individuals at Donner Laboratory and in other departments of the University--in particular, Dr. Lola S. Kelly of Donner for advice during the entire work as well as a personal interest in : my scientific growth. Professor Daniel Mazia of the Department of Zoology. for many stimulating discussions, and Dr. Freddie Sherman, now of the. University of Washington, for valuable suggestions during the studies with yeast. I wish to thank Dr..J. M. Mitchison, of the University of Edinburgh. Edinburgh, Scotland for the original slant of Schizosaccharomyces pombe cells and for encouraging correspondence. Help at various stages of the work and in my graduate program was given by Dr. Ernest Dobson and. Professor Hardin Jones of Donner.

This investigation. was supported (in part) by a fellowship (CF-6688) from the National Cancer Institute, Public Health Service.

Atomic Energy Commission support was provided under contract No. W-7405-èng-48.

The sample of kinetin was kindly supplied by the Upjohn. Chemical Company, Kalamazoo, Michigan. 


\section{BIBLIOGR APHY}

1. C. Darwin and F. Darwin, The Power of Movement in Plants (John Murray, London, 1880).

2. Haagen-Guil, A.J. . Tho Histery and Nature of Plant Growth Hormones in Plant Growth Substances, Folke Skoog, ed. (University of Wisconsin Press, Madison, 1951).

3. K. V. Thimann, Growth and Growth:Hormones in Plants, Am。J. Bot. 44, 49 (1957).

4. F. Skoog, Plant Growth Substances (University of Wisconsin Press, Madison, 1951).

5. A. C. Leopold, Auxins and Plant Growth (Iniversity of California Press, Berkeley, 1955).

6. Miller, Skoog, Von Saltza,.. and Strong, J.Am. Chem. Soc. 77 , 1392 (1955).

7. Miller, Skoog, Okumura, Von Saltza, and Strong, J. Am. Chem. Soc. 78,1375 (1956).

8. G. Pincus and K. V. Thimann, The Hormones, I (Academic Press, New York 1948).

9. R. Snow, New Phytológist 34, 347 (1935).

10. H. C. 'Yin, Proc. Natl. Acad. Sci. U. S. 23, 174 (1937).

11. R. Pratt: Am: J. Bot. 25, 498 (1.938).

12. M. A. Brannon, and. A. F. Bartsch, Am. J. Bot. 26, 27 (1939).

13. M. A. Brannon and. H. M. Sell, Am. J.Bot. 32, 257 (1945).

14. J.R. Roborgh, and J.B. Thomas, Koninkl. Ned. Akad. Wetenschap. Proc。Ser.C. 51, 87 (1948). (In English)

15. S, Lhotský, Ceskoslovenska biologie rŏcnik 3, 45 (1954).

16. M. K. Bach and J. Fellig, Nature 182, 1359 (1958).

17. Street, Griffiths, Thresher, and Owens, Nature 182, 1361 (1958).

18. A. M. Elliot, Trans. Am. Microscop. Soc. 58, 385 (1939).

19. Simone Dao, Compt. rend. 238, 2340 (1954).

20. Niels Nielsen, Zentr. Bakteriol., Parasitenk., Abt. II 82, 70 (1930).

21. A. Ph. Weber, Annales fermentations 3, 15, 65 (1937). 
22. N. G. Kholodny and. K. I. Beltiukova, Mikrobiologiia 8. No. 1, 17 (1939).

23. Loveless, Spoer1, and Weisman, J. Bact. 68, 637.(1954).

24. N. H. Grace, Can. J. Research 15c, 538 (1937).

25. L. Anker, Koninkl。. Ned. Akad. Wetenschap. Proc. Ser. C. 52, 875. (1.949)。

26. R。R..Richards, Botan. Gaz. 110, 523 (1949).

27. E. Ball, J. Bacteriol. 36, 559 (1938).

28. R. J. Dubos, Proc. Soc. Exptl. Biol. Med.63, 317 (1946).

29. P. Handler and. H. Kanin, Proc. Soc. Expt1. Biol. Med.66, 251 (1947).

30. V. Zambotti and B.. DeBernard, Boll. soc. ital. biol. sper. 28, 928 (1952).

31. F. Skoog and C. Tsui, in Plant Growth:Substances (University of Wisconsin Press, Madison, 1951), p. 263.

32. C. O. Miller, Proc. Soc. Expt1. Biol. 83.561 (1953).

33. J.R. Jablonski and F. Skoog, Physiol. Plantarum 7, 16 (1954).

34. K. Patau, N. Das, and.F. Skoog, Physiol. Plantarum 10, 949 (1957).

35. Supniewski, Krupinska, Supniewska, and Waclaw, Bull. Acad. Polon. Sci. II, 5,. No. 1, 19 (1957).

36. J. Supniewski and T. Marczynski. Bull. Acad. Polon. Sci. II, 12, 437 (1957).

37. Ruth Guttman and A. Back, Nature 181, 852 (1958).

38. Skinner, Shive, Ham, Fitzgerald, and Eakin, J.Am. Chem. Soc. 78 , 5097 (1956).

39. J. Brachet, Exptl. Cell Research.14, 650 (1958).

40. Y. Ogawa, op. cit. 15, 415 (1958).

41. H. Lettré and. H. Endo, Naturwiss. 43, 84 (1956).

42. Lansford, Skinner, and.Shive, Arch Biochem. Biophys. 73, 191 (1958).

43. John G. Torrey. (Dept. of Botany, Univ. of Calif.), unpublished personal communication, 1.959.

44. William A. Jensen (Dept. of Botany, Univ. of Calif.), unpublished . personal communication, 1959. 
45. K. V. Thimann, Am. J. Bot: 24, 407 (1937).

46. F. Skoog and C. O. Miller, Symposia Soc. Exptl. Biol. 11, 118-31. (1957).

47. M. Wickson and K. V: Thimann, Physiol. Plantarum 11, 62-74 (1958).

48. L. M. Prescott and. T. W. Janies, Exptl. Coll Roeazrgh 8, 7.5h.8 (1955).

49. Cowie, Roberts, Abelson, Bolton, and Britten, Studies of Biosynthesis in Escherichia coli, Carnegie Inst. of Wash., Publ. No. 607, Washington, D.C. , 1955.

50. J. M. Mitchison, Expt1. Cell Research 13, 244 (1951).

51. R. C. Rustad, Exptl. Cell Research 15, 444 (1958).

52. M. S. Swaminathan and A. T. Gallesall, Nature 182, .610 (1958).

53. F. D. De Lamater, J. Bacteriol. 60, 321 (1950).

54. K. Lietz, Arch. Mikrobiol. 16, 275 (1951).

55. Lindegren, Williams, and McClary, Antonie van Leeuvenhoek, 22, 1 (1956).

56. Thimann, Bonner, and Christiansen, in Changes in Metabolism During Growth and its Inhibition in Plant Growth Substances, F. Skoog, Ed. (University of Wisconsin Press, Madison 1951).

57. F. G. Smith, Respiratory Changes in Relation to Toxicity, ibid.

58. W. A. Worth, Jr。, and A. M. McCabe, Science 108, 16 (1948).

59. Y. L. Hsueh and C. H. Low, ibid. 105, 283 (1947).

60. E. Marrè and G. Forti, Physiol. Plantarum 11, 36-47 (1958).

6 1. Bonner, Bandurski, and Millerd, ibid. 6, 511. (1953).

62. Mitchell, Burris, and Riker, Am. J. Botany 36, 368 (1949).

63. L.J. Audus, New. Phytologist 47, 196 (1948).

64. Hoagland, Stevenson, and Zamecnik, J. Biol. Chem. 231, 241 (1958).

65. A. B. Pardee, Proc. Nat1. Acad. Sci. U.S. 40, 263,(1954).

66. Spiegelman, Halvorson, and Beri-Ishai, in Amino Acid Metabolism and Synthesis of Enzymes in Amino Acid Metabolism,McElroy and. Glass, Ed. (Johns Hopkins Press, Baltimore, 1955).

67. T. Okazaki; and R. Okazaki, Biochim. Biophys. Acta 29, 211 (1958). 
68. L. E. Toliushsis, Biochemistry 23, No. 2, 183 (1958), Translated from Biokhimia 23, No. 2, 194 (1958).

69. E. F. Gale and J. P. Folkes, Nature 173, 1223 (1954).

70. E.F. Gale and.J. P. Folkes, Biochem. J. 69, 611 (1958).

71. G. Zubay, and P. Doty, Biochim, Biophys. Acta 29: 47 (1958).

72. T. Caspersson, Symposia Soc. Exptl. Biol. 1, 127 (1947).

73. E. F. Gale, and J. P. Folkes, Biochem. J. 53, 483. (1953).

74. Caldwell, Mackor, and Hinshelwood, J. Chem. Soc. 3151. (1950).

75. R. McMaster-Kaye and.J.H. Taylor, J. Biophys. Biochem. Cytol, 4. 5 (1958).

76. D. M. Prescott, Exptl. Cell. Research 9, 328 (195.5).

77. D. M. Prescott, paper presented at AAAS meeting, Washington-D. C. , De c. 1958.

78. E. Zeuthen, J. Embryol. Exptl. Morph. 1, 239. (1953).

79. O. Scherbaum and.E. Zeuthen, Exptl. Cell Research 6, 221 (1954).

80. Y. Maruyama, J. Bacteriol. 72, 821 (1956).

81. F. Abbo (Dept. of Biochem., Univ. of Calif.), unpublished personal communications, 1959.

82. T. W. James, Quantitative Studies on the Ribonucleic Acid Content in Amoeba proteus in. Relation to the Nucleus and the Division Cycle (Thesis), University of Calif. , Berkeley, 1954.

83. T. Iwamura, J. Biochem. 42, 575 (1955).

84. J. M. Mitchison and P. M. B. Walker, Exptl. Cell Research 16, 49 (1959).

85. M. P. Rabinovitch and W. Plaut, Exptl. Cell Research.10, 120 (1956).

86. D. Mazia and D. M. Prescott, Science 120, 120 (1956).

87. E. Borek and A. Ryan, J. Bacteriol. 75, 726 (1958).

88. R. Guttman, Chromosoma 8,. 341 (1956).

89. R. Guttman, J. Biophys. Biochem. Cytol. 3, No. 1, 129. (1957).

90. M. Olszewska, Expt1. Cell Research.16, 193 (1959). 
91. Clarke, Elion, Hitchings, and Stock, Cancer Research 18, 445 (1958).

92. R. W. Brockman, M. C. Sparks, and M. S. Simpson, Biochim. Biophys. Acta 26, 671 (1957).

93. M. M. Swann, Cancer Research 17, 727 (1957).

94. D. Mazia, Advances in Biolog. and Med. Phys. 4. 69-118. (1956).

95. M.J. W. Faed, Division and Growth Relationships in..Single Cells (Thesis), Univ of Edinburgh, Edinburgh, Scotland, 1959. 
This report was prepared as an account of Government sponsored work. Neither the United States, nor the Commission, nor any person acting on behalf of the Commission:

A. Makes any warranty or representation, expressed or implied, with respect to the accuracy, completeness, or usefulness of the information contained in this report, or that the use of any information, apparatus, method, or process disclosed in this report may not infinge privalely uwried riglils; or

B. Assumes any liabilities with respect to the use of, or for damages resulting from the use of any information, apparatus, method, or process disclosed in this report.

As used in the above, "person acting on behalf of the Commission" includes any employee or contractor of the Commission, or employee of such contractor, to the extent that such employee or contractor of the Commission, or employee of such contractor prepares, disseminates, or provides access to, any information pursuant to his employment or contract with the Commission, or his employment with such contractor. 